\title{
Exchange Rates and Trade Balances: Effects of Intra-Industry Trade and Vertical Specialization
}

\author{
Rebecca Neumann \\ Department of Economics \\ University of Wisconsin - Milwaukee, Department of Economics \\ Milwaukee, WI, USA \\ Saleh S. Tabrizy ${ }^{* \uparrow+}$ \\ Department of Economics \\ The University of Oklahoma, Department of Economics \\ Norman, OK, USA
}

August 2020

\begin{abstract}
To examine how changes in relative national prices affect trade flows, this study estimates the impact of changes in industry-specific effective real exchange rates on industry-level trade balances, exports, and imports. We analyze the variations in industry-specific intra-industry trade and vertical specialization, which may both govern the long-run relationship between real exchange rates and trade flows. We employ sample information from 13 manufacturing industries across five Asian countries from 2001 to 2015. Rather than country-level aggregate measures, we use disaggregated industry-specific real exchange rates, which provide better measures of relative national prices and may help to uncover different responses that are masked by aggregate data. Fixed-effect estimations reveal that greater price competitiveness, as measured by depreciation in industry-specific effective real exchange rates, increases industry-level trade balances. We find that the elasticity of industry-level trade balances with respect to industry-specific real exchange rates declines as vertical specialization increases. There is also some limited evidence that this elasticity increases as intra-industry trade increases. Taken together, our findings suggest that global supply chains are more important than intra-industry trade in examining the response of trade balances to real exchange rate changes. Importantly, these heterogeneous impacts imply that policies regarding exchange rate management may be of limited potency and will affect different industries in different ways.
\end{abstract}

Keywords: Trade Balance; Exchange Rate; Intra-industry Trade; Vertical Specialization JEL Classification Codes: F14; F31; F41

\footnotetext{
*Corresponding author. Email: tabrizy@ou.edu; ORCID: https://orcid.org/0000-0003-2537-8686

${ }^{+}$We would like to thank the editor and three anonymous referees for their advice and comments. Also, the dataset in use is in part acquired through the University of Oklahoma Libraries Data Grant - we are grateful for the grant. Lastly, we would like to thank Darron Arnold, Shyh Yao Chea, Robert Press, Amir Tayebi, and Zhengag Xu for helpful research assistance.

${ }^{\ddagger}$ Declarations:

Funding: The dataset in use is in part acquired through the University of Oklahoma Libraries Data Grant. Conflicts of interest/competing interests: The authors have no conflicts of interest or competing interests. Availability of data and material: The data in use are organized by third parties including the United Nations Industrial Development Organization, Organization for Economic Co-operation and Development, Research Institute of Economy, Trade, and Industry, World Bank, and International Monetary Fund.

Code availability: The authors provide the estimation codes upon request.
} 


\section{Introduction}

Relative national prices have long been among the key variables in international economics. In particular, economists are interested to know how differences in relative national prices determine the patterns of trade, and how changes in those prices alter trade flows. In this study, we focus on changes in industryspecific effective real exchange rates (IERER), which measure relative national prices at the industry level, and their effects on industry trade balances, exports, and imports. We account for the variations in intra-industry trade and vertical specialization in order to explore the heterogeneities that may exist in the long-run relationship between the exchange rate and trade balances. Generally, a depreciation in a country's currency is expected to harm importers as imports become relatively more expensive while benefitting exporters as exports become relatively less expensive (more competitive) on world markets. More nuanced responses are expected across different industries, however. In particular, these responses may dramatically change if there are greater amounts of intra-industry trade or greater vertical specialization.

Kharroubi (2011) offers country-level evidence for a sample of 20 OECD countries, highlighting two important channels: 1.) an increase in trade within industries, leading countries to trade substitutable products, increases the sensitivity of the trade balance to real exchange rate movements; 2.) an increase in vertical specialization, leading countries to trade complementary products, reduces the sensitivity of the trade balance to real exchange rate movements.

The first channel directly relates to variations in intra-industry trade (IIT). With an increase in IIT in a given industry, a home country increasingly engages in exporting products that are similar to its imports. As a result, import substitutes are more readily available to domestic firms and consumers, who can substitute domestic products for similar imported products when they face an increase in the relative price of imports due to a depreciation in the home currency. To fix intuition, consider two industries in a given country: one with high levels of IIT and one with low levels of IIT. More import substitutes are available in the first industry due to the two-way exchange of similar products (Krugman, Obstfeld, and Melitz, 2012; pp. 164-171). In that industry, consumers are more likely to substitute domestically- 
produced products for imported goods following a real exchange rate depreciation. In the second industry, however, consumers do not find close substitutes for imported goods, which is why imports in that industry may not fall as much in response to a real exchange rate depreciation. Thus, the trade balance in the industry with high levels of IIT is expected to be relatively more sensitive to changes in the real exchange rate, compared to the industry with low levels of IIT. This implies that in the long-run the elasticity of the trade balance with respect to the exchange rate increases as IIT increases.

The second channel relates to variations in vertical specialization (VS). With an increase in $V S$ in a given industry, a home country's exports rely more heavily on imported intermediate goods. As a result, exporters may not benefit from improvements in relative prices following a depreciation in the home currency. Likewise, they may not suffer much from an appreciation of the home currency as their purchasing power of imported content increases, offsetting part of the adverse effects on exports. Again, consider two industries in a given country: one with high levels of VS and one with low levels of VS. In the first industry, exports rely more heavily on imported inputs. In this case, real exchange rate depreciation negatively affects the imports of vertically specialized intermediate goods and, in return, the exports of products that rely on those imported intermediate goods. By contrast, in the second industry, exports do not rely on the imports of intermediate goods. In that industry, exports may benefit from real exchange rate depreciation, as they become relatively more competitively priced on world markets. Thus, the trade balance in industries with high levels of $V S$ is expected to be relatively less sensitive to changes in the real exchange rate, compared to industries with low levels of VS. This implies that in the long-run the elasticity of the trade balance with respect to the exchange rate declines as VS increases.

Kharroubi's (2011) findings at the aggregate level corroborate the impacts noted above, showing that in countries with high levels of intra-industry trade, where trade takes place more within industries, the country-level trade balance is more sensitive to changes in the effective real exchange rate. He also finds that in countries where exports rely heavily on imported content, the country-level trade balance is less sensitive to changes in the effective real exchange rate. However, these country-level results may mask important differences across industries. Some industries may rely more heavily on imported inputs, 
having integrated global supply chains. Such vertical specialization indicates that these industries may respond very differently to changes in the aggregate real exchange rate relative to an industry that has a high degree of intra-industry trade. Thus, rather than relying on country-level variations, we focus on industry level differences.

Importantly, we measure the response of industry-level trade balances to industry-specific exchange rate measures, which provide a relevant measure of relative national prices that are measured more precisely than national exchange rates. Because of differences in industry-level relative national prices, there exist significant variations in industry-specific real exchange rate measures in a given country. Also, sectoral heterogeneities may impact the measurement of real exchange rates as different sectors interact with each other in different ways, affecting both the inter-sectoral linkages and the reliance on traded inputs (Patel, Wang, and Wei, 2019). We allow for heterogeneities in the real exchange rate based on industry prices and account for heterogeneities separately in the trade within and between industries by including the IIT and VS measures in our analysis. These heterogeneities are of importance for policy makers as they consider how exchange rate policies may be used to impact global trade imbalances. For example, an industry with high $I I T$ and low $V S$ may respond strongly to real exchange rate movements, thus impacting the trade balance. Conversely, an industry with low IIT and high VS may exhibit very little response to real exchange rate movements.

To analyze these heterogeneities, we employ industry-level sample information from a panel of 13 manufacturing industries across five leading Asian exporters (including China, Japan, Korea, Malaysia, and Indonesia) from 2001 to 2015. These countries play an important role in global exporting activities. They exported about $\$ 4.15$ trillion in 2015 , which is equal to $19.52 \%$ of world exports and 63.07\% of exporting activities in the East Asia and Pacific region in the same year (World Bank, 2019a). ${ }^{1}$

\footnotetext{
${ }^{1}$ World exports in 2015 were $\$ 21.28$ trillion. In that year, exports from East Asia and Pacific region were \$6.59 trillion, with China’s exports at $\$ 2.36$ trillion, Japan’s exports at $\$ 0.77$ trillion, Korea’s exports at $\$ 0.63$ trillion, Malaysia's exports at \$0.21 trillion, and Indonesia’s exports at \$0.18 trillion.
} 
We employ this sample to examine how changes in IERER affect industry-level trade balances, exports, and imports while accounting for the changes in time-varying industry-specific variations in IIT and VS.

Our findings suggest that in the long-run an increase in price competitiveness, as measured by a depreciation in IERER, contributes to an increase in industry-level trade balances. We show that this longrun relationship is governed by changes in IIT and VS. Without controlling for the variations in IIT and $V S$, our basic estimation results suggest that the absolute value of the elasticity of trade balances with respect to IERER is equal to 0.83 . This implies that a $1 \%$ depreciation in IERER is associated with a $0.83 \%$ improvement in industry trade balances. The absolute value of the above elasticity declines to 0.79 after we include the controls for variations in IIT and VS. More important, keeping all else at their means, our estimations suggest that the absolute value of the above elasticity increases from 0.79 to 0.95 following a one standard deviation increase in IIT from its mean, and that it declines from 0.79 to 0.38 (statistically, indistinguishable from zero) following a one standard deviation increase in VS from its mean. These point estimates suggest that the absolute value of the elasticity of industry trade balances with respect to changes in the real exchange rate is increasing in IIT and decreasing in VS.

The above pattern offers evidence for the presence of heterogenous trade responses to common exchange rate shocks. In contrast to previous work, however, we show that it is the heterogeneities picked up by VS that appear to be more important than those picked up by IIT. As mentioned above, Kharroubi (2011) finds that greater IIT increases the sensitivity of trade balances to aggregate real exchange rate movements. While our coefficients are directionally the same, they are not consistently significant. At best, we conclude that the elasticity of industry trade balances with respect to industry-specific real exchange rate may increase as IIT increases. However, we show more conclusively that the formation of global value chains is quite important to the relationship between industry trade balances and industry real exchange rates. As greater supply chain linkages are made and $V S$ increases, the elasticity declines; this implies that the trade balance becomes less sensitive when exports rely heavily on imported content. The latter effect is particularly important for policy makers. Consider the Electrical Machinery and Apparatus industry as an example. As shown below, it is among the industries with relatively high levels of vertical 
specialization. It is also among the industries that make large contributions to exporting activities in Asia. ${ }^{2}$ Real exchange rate swings are expected to have limited effects on Electrical Machinery and Apparatus exports, despite their large share in manufacturing exports, due to the significant reliance of this industry on imported content. This creates a challenge for policy makers who rely on currency intervention for external adjustments as this industry or similar industries with relatively high reliance on imported inputs will face competing price pressures on imported inputs versus exported final goods.

The findings of this empirical exercise may in part explain why a common shock to the aggregate nominal exchange rate leads to different reactions in different industries or different reactions at different points in time in a given industry. This makes policy decisions on exchange rate management more challenging as these nuanced responses need to be considered. Taken together with the limited significance of the IIT coefficients, these results point to currency intervention being less potent in addressing global imbalances across countries, particularly for industries in which exports rely heavily on imported inputs. Importantly, the responses depend on the amount of interdependence between industries such that global supply chain linkages help determine how responsive trade balances are to real exchange rate movements.

The paper proceeds as follows. Section 2 provides a review of previous empirical findings regarding exchange rate changes and the trade balance at the firm or industry level. Section 3 describes our empirical approach and the data. Section 4 presents the findings of our estimations with conclusions and policy implications in Section 5.

\section{Background}

There have been previous efforts to explore the heterogenous effects of changes in real exchange rates on the trade balance and exporting activities, with an emphasis on differences in productivity, the reliance on

\footnotetext{
${ }^{2}$ To measure the contribution of this industry to manufacturing exports in the countries in our sample, we rely on the median of time-varying share of Electrical Machinery and Apparatus industry's exports in total manufacturing exports. Based on the UN Comtrade data (World Bank, 2017), this share is 37\% for China, $13 \%$ for Indonesia, $20 \%$ for Japan, $28 \%$ for Korea, and $47 \%$ for Malaysia. This industry is ranked as the highest contributor to exports in China, Korea, and Malaysia and second and third highest in Japan and Indonesia, respectively.
} 
imported inputs, and the amount of intra-industry trade. Focusing on the variations in firm-level productivity, Berman, Martin, and Mayer (2012) show that export prices of more productive firms are more sensitive to changes in the real exchange rate, while their export volumes appear to be less sensitive. ${ }^{3}$ Also, focusing on the reliance on imported inputs, Amiti, Itskhoki, and Konings (2014) show that export prices of large exporters who rely on imported inputs are quite sensitive to movements in the real exchange rate when compared to the prices that are set by small exporters with less reliance on imported inputs. In both of these studies, export prices are measured in domestic currency. Unlike the monotonic relationships reported in the above studies, there are other papers that find a U-shaped relationship between market share and pass-through in export prices; e.g., Feenstra, Gagnon, and Knetter (1996), Yoshida (2013), Auer and Schoenle (2016), and Garetto (2016). The findings by Garetto (2016), for example, suggest that up to a certain threshold of market share or productivity, European automobile exporters are more likely to offset part of the exchange rate movements by adjusting their prices. After that threshold, however, they are more likely to pass on the exchange rate movements to their foreign customers, as they have less incentives to engage in strategic pricing. ${ }^{4}$

The differences in firm-level responses may also have important industry-level implications. For example, Berman et al. (2012) provide some sector-level evidence, suggesting that the elasticity of export value with respect to changes in the real exchange rate decreases as sector productivity increases. There are also some timeseries studies that document varying industry-level responses to common exchange rate shocks. Bahmani-Oskooee and Hegerty (2010) survey this literature in detail. Much of this literature, however, focuses on the responses to aggregate (country level) exchange rate changes.

Oguro (2011) and Demiral (2016) provide support for the importance of IIT variations in governing the relationship between the real exchange rate and the trade balance, without controlling for variations in VS separately. Oguro (2011) suggests that the sensitivity of export quantities to changes in

\footnotetext{
${ }^{3}$ These findings are consistent with theoretical models in which demand elasticity is declining in firms' performance (e.g., Melitz and Ottaviano, 2008).

${ }^{4}$ This group of exporters are already among the most productive firms with lowest prices, which may lead them to pass on the exchange rate movements more fully.
} 
the exchange rate declines as IIT increases. Exploring a large panel of industries in multiple countries, she finds that the adverse effects of aggregate bilateral real exchange rate appreciation on industry-level exports are less pronounced in industries with high degrees of IIT, compared to those with low degrees of IIT. Also, exploring Turkey's trade balance with a large set of OECD countries, Demiral (2016) shows that incorporating the variations in IIT may weaken the effect of exchange rate depreciation on exports.

Focusing on the variations in VS, Ahmed et al. (2015) suggest that global supply chain linkages are responsible for the declining elasticity of manufacturing export volumes to aggregate real exchange rate swings at both the country and industry level. However, Leigh et al. (2017) find no conclusive evidence for the moderating effects of VS variations; even though the share of VS-related trade is gradually increasing, they argue that conventional trade still dominates the relatively small share of trade in intermediate inputs, which could in part justify the obtained evidence in their research. More recently, Bussiere, Gaulier, and Steingress (2020) estimate trade elasticities using product level data from a wide range of countries. They highlight the importance of the import content of exports, suggesting that the magnitude of the estimated elasticities depends on the correlation between exchange rate and unobserved marginal costs which, in return, depend on imports cost.

Motivated by these studies, we examine how industry-specific IIT and VS govern the relationship between industry IERER and industry trade balances. The contributions of our paper are threefold. First, compared to Kharroubi (2011), we examine industry-level trade balance variations, exploiting the significant differences in IIT and $V S$ across different industries within a given country. We also employ an industry-specific measure for real exchange rates. We exploit the significant differences that are observed in exchange rates across different industries within a given country. Aggregate variations may mask these differences. Second, compared to Oguro (2011) and Demiral (2016), we control for variations in IIT and VS separately, which enables us to draw clear inference. Also, compared to Leigh et al (2017), we focus on a sample of leading Asian exporters who are heavily engaged in trade of intermediate inputs. In this environment, the control for $V S$ and its interaction with IERER allow us to capture the effects of differences in vertical relationships. Third, we examine the changes in the elasticity of industry trade 
balances with respect to industry IERER over the entire distribution of IIT and VS. This exercise provides a detailed estimate of the changes in the elasticity based on the heterogeneities across industries.

\section{Empirics}

In this section, we first describe the data in use. We then introduce our regression functions, describing the key parameters that govern the long-run relationship between IERER and industry-level trade balances, exports, and imports.

\subsection{Data}

We use annual data from 2001 to 2015 for five leading exporters in Asia: China, Indonesia, Japan, Korea, and Malaysia..$^{5}$ In each country, we examine 13 two-digit manufacturing industries. We list those industries in Table 1. While industry-level trade data are available for a large set of countries in east and southeast Asia, the industry-level data on output, VS, and IERER variations are limited, thus limiting the countries available for consideration. For the countries that we study in this paper, we have access to comprehensive data on industry-level exports, imports, trade balances, IIT, VS, IERER, and output, allowing us to examine how changes in IIT and VS may affect the exchange rate elasticity of trade balances.

\subsubsection{Trade Data, Intra-Industry Trade (IIT), and Vertical Specialization (VS)}

The data for industry-level exports and imports are provided by the UN Comtrade. We access this dataset through World Integrated Trade Solution (World Bank, 2017). Export and import values are reported annually and are measured in US dollars.

Consider country $c$. We measure the industry-specific trade balance for industry $i$ in country $c$ at time $t$ using the natural log of the ratio of industry $i$ 's exports over its imports:

$$
\log \left(T B_{c i, t}\right)=\log \left(\frac{\operatorname{Exports}_{c i, t}}{\operatorname{Imports}_{c i, t}}\right)=\log \left(\operatorname{Exports}_{c i, t}\right)-\log \left(\operatorname{Imports}_{c i, t}\right)
$$

\footnotetext{
${ }^{5}$ Hong Kong and Macao's data are excluded from the industry-level observations for China.
} 
Table 2 reports the median trade balances by industry. Also, Figure A1 in the appendix plots the timeseries of industry-specific trade balances for the industries that are included in our dataset for each country. Lastly, Figure A2 provides a histogram of trade balances across all countries in the dataset.

We use UN Comtrade data to measure export and import intensities for our country-industry pairs. We divide the industry-specific exports for industry $i$ in country $c$ at time $t$ by its output to measure export intensity of that particular country-industry pair. We form a similar ratio for import intensity.

Table 2 reports the median export and import intensities for the industries that are included in our sample.

We measure industry-specific IIT using the export and import data. Consider industry $i$ in country $c$ at time $t$. We use the following ratio, as proposed by Krugman et al. (2012; p. 170), to measure the IIT for industry $i$ :

$$
I I T_{c i, t}=\frac{\operatorname{Min}_{\text {Exports } \left._{c i, t}, \text { Imports }_{c i, t}\right\}}}{\left(\text { Exports }_{c i, t}+\operatorname{Imports}_{c i, t}\right) / 2}
$$

An increase in the above measure represents an increase in international trade within a given industry. To fix intuition, consider a hypothetical industry that only exports to the rest of the world and does not import anything. There is no trade within this industry, and the IIT measure is equal to zero. Analogously, consider another hypothetical industry that imports as much as it exports. There is a high amount of trade within this industry, and the IIT measure is equal to 1 . Thus, an increase in the above measure is an indication of an increase in trade in similar goods within a given industry.

In Figure 1, we plot the medians of the time-varying IIT measure for all of the country-industry pairs in our sample. This figure shows that there are considerable differences in intra-industry trade across different industries in a given country. Take Indonesia, for example. While there is a small amount of IIT in wood products (the median of IIT measures from 2001 to 2015 is equal to 0.15 ), there is a large amount of IIT in metal products (the median of IIT measures from 2001 to 2015 is equal to 0.89 ). In Table 2, we report the median IIT for the industries that are included in our sample.

To account for vertical specialization, we use the input-output data from the OECD (2019), which includes an industry-specific measure for VS. The OECD computes this measure using the general 
approach outlined in Hummels, Ishii, and Yi (2001). Vertical specialization in industry $i$ in country $c$ at time $t$ is generally computed as:

$$
V S_{c i, t}=\frac{\text { IntImports }_{c i, t}}{Y_{c i, t}} \times \text { Exports }_{c i, t}
$$

where IntImports $s_{c i, t}$ measures the amount of imported intermediate goods that are used in production, and $Y_{c i, t}$ measures gross production. The above measure is, in essence, a weighted measure for industry-level exports. However, the classification scheme that identifies a product as an intermediate input may be arbitrary, and there may be some imported intermediate inputs that are used indirectly in the production of an exported product. To overcome these problems, Hummels et al. (2001) suggest using input-output tables, as they do not require any arbitrary classification and they allow for measuring indirect links in production.

To fix intuition, suppose that country $c$ has $n$ industries. Let $u$ be a $1 \times n$ vector of $1 \mathrm{~s}$ and $I$ be the identity matrix. $A^{M}$ is an $n \times n$ matrix of imported coefficients in which element $a_{i, j}{ }^{M}$ measures the value of imported inputs from industry $i$ that are employed in production of one unit of output in industry $j . A^{D}$ is an $n \times n$ matrix of domestic coefficients in which element $a_{i, j}{ }^{D}$ measures the value of domestic inputs from industry $i$ that are employed in production of one unit of output in industry $j$. Let $X$ be an $n \times 1$ vector of exports. Finally, let $X_{c}$ be the sum of county c's exports. The adjusted measure of vertical specialization in Hummels et al. (2001) is then given by:

$$
V S_{c}=u A^{M}\left[I-A^{D}\right]^{-1} X / X_{c}
$$

One can compute the above measure at country- or industry-levels (e.g., OECD 2010, p. 225). One can also compute this measure for country-industry pairs. We employ the country-industry-specific measure of vertical specialization, computed by the OECD (2019). For manufacturing industries under ISIC Rev. 3 classification, this measure is available from 2001 to 2011.

In Figure 2, we plot the medians of the time-varying VS measure for all of the country-industry pairs in our sample. Similar to IIT, there are considerable differences in vertical specialization across different industries in a given country. Consider Indonesia again. While there is a small amount of VS in 
food products (the median of VS measures from 2001 to 2011 is equal to 0.09 in the food industry), there is a large amount of $V S$ in general machineries (the median of $V S$ measures from 2001 to 2011 is equal to 0.38 in this industry). Also, in Table 2, we report the median $V S$ for the industries that are included in our sample.

As discussed in Sections 1 and 2, we employ the variations in IIT and $V S$ to see how the exchange rate elasticity of trade balance is governed by changes in trade within industries and reliance on imported inputs through global supply chain linkages. ${ }^{6}$ There are cross-country differences between IIT measures for a given industry; the same is true for the $V S$ variations (see Figures 1 and 2). ${ }^{7}$ These differences may be the result of cross-country differences in factor endowments, factor prices, and market size, along with cross-country differences in trade barriers (e.g., tariffs and non-tariff measures) ${ }^{8}$

By focusing on a given industry, one may bypass the cross-industry differences in the degree of product differentiation and internal economies of scale. In that case, the cross-country differences in factor endowments and market size remain as important determinants of IIT variations: the greater the difference in factor composition or the smaller the market size, the lower the IIT share in trade. ${ }^{9}$ It is, thus, not surprising to see that leading transportation equipment producers, like Japan and Korea, engage less in IIT. Considering their favorable factor composition, they engage heavily in exporting activities. Yet, their domestic market is not sufficiently large for imports. As a result, they exhibit relatively low IIT, when compared to China (Figure 1).

\footnotetext{
${ }^{6}$ Figures A3 and A4 in the appendix show the histogram of IIT and $V S$ variations across all country-industry pairs. Figure A5 shows the scatterplot for industry-specific medians of time-varying $I I T$ and $V S$, by country.

${ }^{7} \mathrm{We}$ are grateful to an anonymous referee for raising this point.

${ }^{8}$ For cross-country IIT variations, for example, models that are developed by Markusen and Venables (2000) and Helpman, Melitz, and Yeaple (2004) suggest that trade barriers may create incentives for horizontal FDI in the destination country; in return, horizontal FDI may lower the amount of IIT. Veeramani (2009) offers empirical evidence that support the importance of this interaction for the IIT pattern in India.

${ }^{9}$ See Helpman and Krugman (1985) and Helpman (2011, pp. 79-95) for a theoretical justification of why IIT is expected to decrease when the difference in factor composition increases; Helpman (1987), Clark and Stanley (1999), and Cieslik (2005) offer empirical support for this proposition. Beyond relative factor endowments, there are also some models suggesting that cross-country differences in technology (Falvey, Greenaway, and Yu, 2011) and productivity (Song and Sohn, 2012) may determine the IIT patterns.
} 
Similarly, by focusing on a given industry, one may bypass the cross-industry differences in unit factor requirements as given by varying industry-specific production functions. In that case, the crosscountry differences in factor endowments and factor prices remain as important determinants of the $V S$ variations. ${ }^{10}$ The importance of factor endowments is well-illustrated in the VS variations for petroleum products across four countries in our sample. While Indonesia and Malaysia benefit from an abundance of oil resources (OPEC, 2020), Japan and Korea rely heavily on imported petroleum products. This difference in factor endowments is reflected in the $V S$ variations for petroleum products industry across these countries (Figure 2). Also, the importance of factor prices is illustrated in the $V S$ variations for electrical machinery as well as optical and precision instruments industries. When compared to Japan, countries like China, Indonesia, and Malaysia enjoy lower relative factor prices. That, in return, provides domestic and multinational firms with an incentive to import intermediate inputs and engage in vertical FDI, respectively, which contributes to greater $V S$ values (Figure 2).

Lastly, the unconditional coefficient of correlation between IIT and VS is about 0.31 . This implies that we can safely employ them together in our regression analyses. Table A1 in the appendix reports the country-specific correlation coefficients for median and overall variations in IIT and VS. These correlation coefficients range from -0.12 to 0.39 .

\subsubsection{IERER Data:}

As an important contribution to the analysis of the impact of changes in the exchange rate on the trade balance, we employ a measure for industry-specific exchange rates rather than relying on aggregate measures of nominal or real exchange rates. ${ }^{11}$ Using this measure, we estimate the effect of changes in industry-specific relative national prices on industry-level trade balances, exports, and imports. The measure for IERER is provided by the Research Institute of Economy, Trade, and Industry (2017). This

\footnotetext{
${ }^{10}$ See Helpman (1984) and Helpman (2011, pp. 142-146) for a theoretical discussion of why differences in factor endowment and factor prices incentivize multinationals to engage in vertical FDI, providing their subsidiaries with intermediate inputs. Also, see Grossman and Rossi-Hansberg (2008) for a detailed discussion of task trade and Antràs and Helpman (2004) for the organizational forms arising from global sourcing.

${ }^{11}$ Industry-specific exchange rate measures are increasingly used in empirical research in international economics. Recent examples include Tabrizy (2020) and Nguyen and Sato (2020).
} 
measure is a function of aggregate nominal exchange rates, industry-specific producer price indexes, and industry-specific trade weights. Consider industry $i$ in countries $c$ and $f$ at time $t$. Sato et al. (2015) define the industry-specific effective real exchange rate for industry $i$ as:

$$
I_{E R E R_{i, t}}=\prod_{f=1}^{n}\left(B R E R_{i, t}^{(f)}\right)^{\alpha_{i, t}^{(f)}}
$$

where $B R E R_{i, t}^{(f)}$ is the industry-specific bilateral real exchange rate, $n$ is the number of trade partners for industry $i$ in country $c$, and $\alpha_{i, t}^{(f)}$ is the share of exports to country $f$, varying between 0 and 1 . The industry-specific bilateral real exchange rate $\left(B R E R_{i, t}{ }^{(f)}\right)$ is defined as:

$$
B R E R_{i, t}^{(f)}=\frac{\left(\frac{1}{N E R_{f, t}^{(c)}}\right) \times P_{i, t}^{(c)}}{P_{i, t}^{(f)}}
$$

In Equation 6, $N E R_{f, t}^{(c)}$ stands for the nominal exchange rate, defined as the price of country $f$ 's currency measured in country $c$ 's currency. $P_{i, t}^{(c)}$ and $P_{i, t}^{(f)}$ are industry $i$ prices in countries $c$ and $f$, respectively. The measure given by Equation 6 is the ratio of industry-specific price in country $c$ (measured in country $f$ 's currency) over the industry-specific price in country $f$ (measured in country $f$ 's currency). To understand the implication of changes in this measure, we may normalize the denominator: $P_{i, t}(t)$. For a given nominal exchange rate (fixed $N E R_{f, t}{ }^{(c)}$ ), a decline in country $c$ 's prices (i.e., greater price competitiveness) would imply a decrease in $B R E R$, which is considered a real depreciation. For a given price level in country $c\left(\right.$ fixed $\left.P_{i, t}^{(c)}\right)$, an increase in the nominal exchange rate (i.e., depreciation of country c's currency) would imply a decrease in $B R E R$, which is again a real depreciation. Thus, greater price competitiveness or depreciation in country c's currency, which may both contribute to trade balances through an increase in exports, imply a real depreciation for country $c$. In practice, however, countries have multiple trade partners. Thus, for a given industry, there are multiple bilateral real exchange rates. In addition, the amount of exports to different trade partners may vary. That is why Sato et al. (2015) employ the share of exports to each destination in order to construct an industry-specific 
effective real exchange rate measure as given in Equation $5 .{ }^{12}$ Similar to BERER, a decrease in IERER corresponds to a depreciation of the industry-specific effective real exchange rate, implying greater price competitiveness.

The Research Institute of Economy, Trade, and Industry (2017) reports this measure on a daily and monthly basis for the industries that are listed in Table 1. Together, these industries represent the manufacturing sector. The only manufacturing industries that are missing in the IERER dataset are the production of furniture and recycling activities (ISIC R3 codes 36 and 37, respectively). The remainder of manufacturing industries are included. Also, to match the annual variations in industry-specific exports, imports, and output, we use the monthly variations to compute the average annual IERER as our measure of relative national prices for each industry in each country.

Figure 3 plots the timeseries of IERER measure for all of the industries that are included in our dataset. For illustration purposes, the variations are adjusted by first normalizing the IERERs such that they are all equal to 100 for the year 2001, and then taking natural log; that way, we may make a straightforward comparison between different timeseries. Figure 3 shows that there are a great deal of heterogeneities in the level of IERER measures in a given country. These measures not only take into account the country-specific exchange rates $\left(N E R_{f, t}{ }^{(c)}\right)$, they also include the industry-specific prices $\left(P_{i, t}{ }^{(c)}\right.$ and $\left.P_{i, t}^{(f)}\right)$ and export shares $\left(\alpha_{i, t}^{(f)}\right)$. By contrast, an aggregate measure of the real exchange rate does not take into account the industry-specific prices and their export shares separately.

The country-industry-specific measure that we employ in this study enables us to capture the heterogeneities in industry-specific relative national prices. It also improves the measurement of our key independent variable. As expected, the IERER measures are correlated across different industries in a given country and across different countries for a given industry. ${ }^{13}$ To remedy for these correlations, we

\footnotetext{
${ }^{12}$ See Chinn (2006) for a primer on calculating different measures of effective exchange rates at the country level. ${ }^{13} \mathrm{We}$ are grateful to an anonymous referee for raising this point. There are two reasons for the correlation between the IERER measures within a given country. First, the IERER measure is a function of the nominal exchange rate $\left(N E R_{f, t}{ }^{(c)}\right)$, which is country-specific and common for all industries. Second, industry-specific price measures $\left(P_{i, t}{ }^{(c)}\right)$ may respond to common shocks; e.g., monetary expansions or contractions, productivity shocks, factor market shocks, etc. We also expect some correlations between the IERER measures in different countries. For example,
} 
include a fixed effect parameter and a vector of time dummies in our regression functions. Plus, as part of our robustness tests, we control for country dummies, industry dummies, country-time dummies, and industry-time dummies. Along with other control covariates, the above dummies are expected to reduce the unconditional correlations.

\subsubsection{Output Data:}

We control for the variations in outputs, and we make use of output for computing the export and import intensities. We employ the OECD STAN (2020) dataset to obtain industry-specific output data for Japan and Korea. Output values are reported annually, measured in local currency. We use the average annual nominal exchange rate to convert the reported values in the OECD STAN dataset to US dollars. ${ }^{14}$ Using the data for ISIC Rev. 4 classification, we are able to employ industry-specific output data for the majority of industries in Japan and Korea from 2001 to 2015.

We use the UNIDO INDSTAT4 (2017) dataset to obtain industry-specific output data for China, Indonesia, and Malaysia. ${ }^{15}$ Industry output values are reported annually and are measured in US dollars. We primarily use the ISIC Rev. 3 industry classification but augment this with ISIC Rev. 4 data to extend the time coverage. We aggregate the information from three-digit industries to obtain the output information for the two-digit (ISIC Rev. 3 code) industries that are listed in Table $1 .{ }^{16}$ Using the ISIC Rev. 3 data, we are able to employ industry-specific output data for China from 2003 to 2011, for Indonesia from 2001 to 2009, and for Malaysia from 2001 to 2008. Augmenting this with ISIC Rev. 4 data, we add further information for many industries in Indonesia (up to 2013) and Malaysia (up to 2010). Thus, overall data coverage is for China 2003 to 2011, Indonesia 2001 to 2013, Malaysia 2001 to 2010, Japan 2001 to 2015, and Korea 2001 to 2015.

\footnotetext{
industry-specific productivity shocks that are common among leading exporters may cause a correlation between the IERER measures in different countries. Correlation coefficient matrices are available upon request.

${ }^{14} \mathrm{We}$ use the amount of national currency per US dollar (period average) as our measure for the nominal exchange rate. The data is from the IMF's International Financial Statistics (2020).

${ }^{15}$ The industry-level output data for these countries are not available in the OECD STAN dataset.

${ }^{16}$ For example, for the food industry, ISIC R3 three-digit codes 151, 1520, 153, 154, 155, and 1600 are combined into the two-digit code 15-16, and similarly for other industries. For details on the two- and three-digit codes, see United Nations Statistics Division (2002).
} 
We also use the dataset provided by Jorgenson, Ho, and Samuels (2018) to capture the effect of industry-specific output variations in the US. ${ }^{17}$ While controlling for the home country's output captures the variations that relate to the supply side, controlling for US output may in part capture the variations that relate to the demand side. The US is an appealing choice as it is an important export destination for the countries that we study. Data from the IMF (2020) suggest that the US is the most important export destination for China and Japan, the second most important export destination for Korea, and the fourth most important export destination for Indonesia and Malaysia during the last year for which we observe the industry-level data for these countries. Thus, by employing US industry-specific output, we can capture an important source of foreign demand variations for the countries in our dataset.

Lastly, we control for country-specific real GDP and for US real GDP. We use World Bank (2019b) data for gross domestic products in constant 2010 prices, measured in US dollars. Controlling for country-specific GDP variations, we are able to capture domestic and foreign business cycle effects that are not fully captured by industry-specific output variations.

\subsection{Empirical Approach}

\subsubsection{Regressions for the Trade Balance}

Using our panel data, we employ a fixed-effect model for baseline estimations. We use country-industry pairs as cross-section observations along with annual time variations, so that we have a panel across country-industry-time data units. Analogous to Kharroubi (2011) who explores the country-level trade balance, our main dependent variable is the industry-level trade balances. Importantly, the independent variable of interest in this paper is the IERER, a disaggregated industry-specific measure of the real exchange rate rather than a country-level exchange rate. We specify our trade balance regression in Equation 7:

\footnotetext{
${ }^{17}$ This dataset provides us with the industry-specific output data until 2014 but does not include information for 2015. It also does not include the optical instrument industry. We use the OECD STAN dataset to obtain the output measure for the optical instrument industry in the US.
} 


$$
\begin{aligned}
\log \left(T B_{c i, t}\right)= & \alpha_{1} \log \left(\operatorname{IERER}_{c i, t}\right)+\alpha_{2} I I T_{c i, t}+\alpha_{3} I I T_{c i, t} \times \log \left(\operatorname{IERER}_{c i, t}\right) \\
& +\alpha_{4} V S_{c i, t}+\alpha_{5} V S_{c i, t} \times \log \left(\operatorname{IERER}_{c i, t}\right)+X_{c i, t}^{\prime} \beta+T^{\prime} \gamma+\delta . t+\eta_{c i} \\
& +\varepsilon_{c i, t}
\end{aligned}
$$

$T B_{c i, t}$ is the trade balance of country-industry pair $c i$ at time $t$. IERER $R_{c i, t}$ is the effective real exchange rate for country-industry pair $c i$ at time $t . I I T_{c i, t}$ is the time-varying measure of intra-industry trade for countryindustry pair $c i$ at time $t$, and $V S_{c i, t}$ is the time-varying measure of vertical specialization for the same country-industry pair during the same time period. $X$ is a vector of control covariates, including domestic and foreign industry output and GDP. $T$ is a vector of time dummies. $t$ is the annual time trend. $\eta_{c i}$ is the fixed-effect parameter, capturing time-invariant idiosyncratic characteristics of country-industry pairs. The fixed-effect parameter is allowed to be correlated with independent variables. Lastly, $\varepsilon_{c i, t}$ is the error term under the usual assumptions. ${ }^{18}$

As described in Sections 1 and 2, an increase in IIT may increase the sensitivity of industry trade balances to real exchange rate depreciation as domestic consumers switch more easily to import substitutes. Conversely, an increase in VS may decrease the sensitivity of industry trade balances to real exchange rate depreciation as domestic producers find it harder to export at competitive prices due to the increase in the relative price of imported intermediate inputs. The interactions in Equation 7 allow us to explore the heterogeneities in responses over the entire distribution of IIT and VS. Using these interaction terms, we examine how the long-run relationship between IERER and industry-level trade balances is governed by changes in IIT and $V S$. Kharroubi (2011) employs similar interaction terms using aggregate real exchange rates and trade balances. ${ }^{19} \mathrm{We}$ follow his approach but we examine industry-level sample evidence, employing industry-level measures of the real exchange rate.

\footnotetext{
${ }^{18} \mathrm{We}$ assume that the mean of $\varepsilon_{c i, t}$ is equal to zero. We also assume that it is uncorrelated with itself, IERER, the control covariates, and the fixed-effect parameter.

${ }^{19}$ Berman et al. (2012) make use of similar interaction terms, exploring the effect of heterogeneities that stem from firm- and sector-level productivity. Ahmed et al. (2015) also use similar interactions in exploring the effect of global value chains.
} 
We are primarily interested in the elasticity of industry-level trade balance with respect to changes in IERER. This elasticity is a function of both IIT and VS and can be estimated using the parameters in Equation 7 as: $\alpha_{1}+\alpha_{3} I I T_{c i, t}+\alpha_{5} V S_{c i, t}$. After estimating $\alpha_{1}, \alpha_{3}$, and $\alpha_{5}$, we keep IIT $T_{c i, t}$ and $V S_{c i, t}$ at their unconditional mean to estimate the overall effect of exchange rates and examine its significance. We then explore the heterogeneity in responses. We first keep $V S_{c i, t}$ at its unconditional mean and allow $I I T_{c i, t}$ to vary so we can examine how changes in $I I T$ affect the elasticity of interest. Similarly, we keep $I I T_{c i, t}$ at its unconditional mean and allow for $V S_{c i, t}$ to vary so we can examine how changes in $V S$ affect the elasticity of interest. In each case, we provide confidence intervals indicating the significance of the calculated elasticity, which depends not only on the parameters but also on the realizations of $I I T$ and $V S$.

\subsubsection{Regressions for Exports and Imports}

We also examine the effects of changes in industry real exchange rates on exports and imports separately. For this purpose, we normalize the industry-specific variations in exports and imports using industryspecific variations in output. Employing intensity measures as dependent variables, we specify our exports and imports regression in Equations 8 and 9:

$$
\begin{aligned}
\log \left(x_{c i, t}\right)=\alpha_{1} & \log \left(\operatorname{IERER}_{c i, t}\right)+\alpha_{2} I I T_{c i, t}+\alpha_{3} I I T_{c i, t} \times \log \left(\operatorname{IERER}_{c i, t}\right) \\
& +\alpha_{4} V S_{c i, t}+\alpha_{5} V S_{c i, t} \times \log \left(\operatorname{IERER}_{c i, t}\right)+X_{c i, t}^{\prime} \beta+T^{\prime} \gamma+\delta . t+\eta_{c i} \\
& +\varepsilon_{c i, t}^{x} \\
\log \left(m_{c i, t}\right)= & \alpha_{1} \cdot \log \left(\operatorname{IERER}_{c i, t}\right)+\alpha_{2} I I T_{c i, t}+\alpha_{3} I I T_{c i, t} \times \log \left(\operatorname{IERER}_{c i, t}\right) \\
& +\alpha_{4} V S_{c i, t}+\alpha_{5} V S_{c i, t} \times \log \left(\operatorname{IERER}_{c i, t}\right)+X_{c i, t}^{\prime} \beta+T^{\prime} \gamma+\delta . t+\eta_{c i} \\
& +\varepsilon_{c i, t}^{m}
\end{aligned}
$$

where $x_{c i, t}$ is the exports of country-industry pair $c i$ at time $t$, divided by its output, and $m_{c i, t}$ is the imports of country-industry pair $c i$ at time $t$, divided by its output. In Equation 8, we control for $m_{c i, t}$ as part of the $X$ vector. Similarly, in Equation 9, we control for $x_{c i, t}$. Again, $I I T_{c i, t}$ and $V S_{c i, t}$ are measures of intraindustry trade and vertical specialization for country-industry pair $c i$ at time $t$, respectively. Similar to 
Equation 7, the elasticity parameter in Equations 8 and 9 can be calculated as: $\alpha_{1}+\alpha_{3} I I T_{c i, t}+\alpha_{5} V S_{c i, t}$.

We estimate the overall effect by keeping $I I T_{c i, t}$ and $V S_{c i, t}$ at their unconditional mean. We, then, estimate the heterogeneities by allowing $I I T_{c i, t}$ and $V S_{c i, t}$ to vary one at a time while keeping the other one at its unconditional mean.

\section{Results}

\subsection{Trade Balance}

We report our trade balance regression results in Table $4 .{ }^{20} \mathrm{We}$ employ robust standard errors clustered at the country-industry level; e.g., Food industry in China. As a result, the observations are kept independent across different country-industry pairs. In columns $I$ and $I I$, we report the estimation results without controlling for the variations in IIT and VS. All else constant, the results suggest that greater price competitiveness, as measured by a real depreciation (decrease in IERER), contributes to increases in industry-level trade balances. ${ }^{21}$ In absolute value, the results in column $I I$ suggest that the elasticity of industry-level trade balances with respect to changes in IERER is about 0.83 , implying that a $1 \%$ depreciation in IERER is associated with a $0.83 \%$ improvement in industry trade balances.

As the key contribution of this paper, we examine how variations in IIT and VS may govern the relationship between IERER and industry-level trade balances. We report the results in columns III through VII in Table 4, where we consider different controls in vector $X$. Take column VII, for example. It includes the estimation results for the full set of parameters in Equation 7, including the industry outputs $\left(\log (Q)\right.$ and $\log \left(Q^{U S}\right)$ for the domestic and US industry outputs) and country-level GDPs $(\log (Y)$ and $\left.\log \left(Y^{U S}\right)\right)$. The coefficient associated with $\log (I E R E R)$ is negative and significant. The coefficient

\footnotetext{
${ }^{20} \mathrm{We}$ employ sample information from 13 manufacturing industries across five Asian countries over 15 years, from 2001 to 2015. In an unbalanced panel with no missing information, we would have had access to $975(=13 \times 5 \times 15)$ observations. As described in Section 3.1.3, however, we do not have access to some of the information for domestic and US industry-specific output data. Also, as indicated in Section 3.1.1, we have access to VS information only from 2001 to 2011. Thus, our sample size declines further when we include the control for $V S$ and its interaction with IERER.

${ }^{21}$ We obtain similar results when we limit our sample to the observations that are used in the estimations with IIT and $V S$ variations (e.g., Table 4, column $V I$ ).
} 
associated with the interaction between IIT and $\log (I E R E R)$ is negative, but not significant. ${ }^{22}$ The coefficient associated with the interaction between $V S$ and $\log (I E R E R)$ is positive and significant. ${ }^{23}$ This pattern highlights the importance of $V S$ variations, indicating that global supply chains may be a more important feature than the amount of IIT in the relationship between real exchange rates and industry trade balances. As mentioned previously, however, the elasticity of industry-level trade balances with respect to IERER is a function of both IIT and VS. Thus, to fully understand their effects, we go beyond the significance of the individual point estimates and compute confidence intervals for the elasticity of interest over the entire distribution of IIT and $V S$.

To compute confidence intervals, we rely on the results reported in column VI of Table 4 in which we control for industry-specific covariates, including $I I T, V S, \log (Q)$, and $\log \left(Q^{U S}\right)$, along with time dummies, time trend, and fixed effect. Though the results in column VI are quite similar to the results in column VII, we only use industry-level covariates in column VI (dropping the country-level GDP values), which enables us to compute the confidence intervals for varying levels of IIT and VS.

Table 5 reports the computed confidence intervals in detail, providing evidence on the significance of the calculated elasticity. Keeping all variables (including IIT and VS) at their unconditional means, the absolute value of the point estimate for the elasticity of trade balance with respect to IERER is equal to 0.79 . In absolute value, the $95 \%$ confidence interval in this case is bounded between 0.25 and 1.32. We re-estimate this confidence interval at a higher level of IIT and VS. First, except for the variations in IIT, we keep all variables (including $V S$ ) at their unconditional means and recalculate the above elasticity at a higher level of IIT, deviating one standard deviation from its unconditional mean. ${ }^{24}$ In this case, the absolute value of the point estimate for the elasticity of trade balance with respect to IERER is equal to 0.95 . The absolute value of its $95 \%$ confidence interval

\footnotetext{
${ }^{22}$ This coefficient is significant at $5 \%$ level of significance when we do not cluster our standard errors.

${ }^{23}$ The same pattern emerges if we drop Japan and Korea's petroleum industries that have relatively high VS values (Figures 2 and A5). We are grateful to an anonymous referee who motivated this test. Detailed estimation results are available upon request.

${ }^{24}$ The unconditional mean for $I I T$ is equal to 0.62 , with standard deviation being equal to 0.27 . Deviating one standard deviation from the mean, IIT increases to 0.89 .
} 
estimation is between 0.10 and 1.79. Thus, one standard deviation increase in IIT away from its mean is associated with an increase in the point estimate for the absolute value of the elasticity of interest. Second, except for the variations in $V S$, we keep all variables (including IIT) at their unconditional means and recalculate the above elasticity at a higher level of $V S$, deviating one standard deviation from its unconditional mean. ${ }^{25}$ In this case, the absolute value of the point estimate for the elasticity of trade balance with respect to IERER is equal to 0.38 . Statistically, this point estimate is not distinguishable from zero. Thus, unlike IIT, one standard deviation increase in $V S$ away from its mean is associated with a decline in the point estimate for the absolute value of the elasticity of interest.

We also examine the elasticity of interest over the range of variations in IIT (Figure 4) and VS (Figure 5) given the estimation results reported in column VI of Table $4 .{ }^{26}$ Holding other variables at their unconditional means, we estimate the confidence interval for the elasticity at the smallest value of IIT. We then re-estimate the confidence interval assuming that IIT increases by $10 \%$, up to the largest value of IIT. We repeat the same exercise using the variations in $V S$.

Keeping all else constant at their means, Figure 4 shows that as the IIT measure increases (i.e., when more import substitutes are available), the average marginal effect of IERER becomes more significant. The average marginal effect of IERER is statistically not different from zero at the left-hand side of the IIT distribution, when the IIT index increases from 0.15 to 0.215 . However, the marginal effect of interest is statistically significant as the IIT index increases from 0.315 to 0.915 . In their absolute values, the point estimates of the confidence intervals, used as our estimate for the elasticity of industrylevel trade balance with respect to IERER, increase as the IIT index increases.

Keeping all else constant at their means, Figure 5 shows that as the $V S$ measure increases (i.e., when exports rely more on imported intermediate goods), the average marginal effect of IERER becomes less significant. The average marginal effect of IERER is statistically significant at the left-hand side of

\footnotetext{
${ }^{25}$ The unconditional mean for $V S$ is equal to 0.29 , with standard deviation being equal to 0.16 . Deviating one standard deviation from the mean, $V S$ increases to 0.45 .

${ }^{26}$ See Figures A3 and A4 for the histogram of variations in IIT and VS measures among the above observations.
} 
the VS distribution, when the VS index increases from 0.052 to 0.352 . However, the marginal effect of interest becomes statistically insignificant as the $V S$ index increases from 0.452 to 0.752 . In their absolute values, the point estimates of the confidence intervals decrease as the VS index increases.

Thus, as theorized in Section 1, the results from our regressions show that the elasticity of industry trade balances to changes in IERER increases in absolute value as IIT increases or VS declines. However, the effects from variations in IIT are less significant when compared to variations in $V S .{ }^{27}$ This is illustrated in relatively large confidence intervals in Figure 4 compared to Figure 5. Nonetheless, our findings suggest that exchange rate swings have significant effects on industry-level trade balances, in particular when IIT increases or VS declines.

In terms of the control variables, the results in Table 4 suggest that domestic industry output, $\log (Q)$, and foreign industry output, $\log \left(Q^{U S}\right)$, are both positively correlated with industry trade balances. Across almost all specifications, $\log (Q)$ and $\log \left(Q^{U S}\right)$ remain significant. For $\log (Q)$, however, the pvalue increases to $13 \%$ and $11 \%$ in the results reported in columns $V I$ and $V I I$, respectively. As for the variations in real GDP, we find no significant correlation between domestic aggregate output, $\log (Y)$, and industry-level trade balances. However, we find that foreign aggregate output, $\log \left(Y^{U S}\right)$ is positively correlated with industry-level trade balances, suggesting that foreign income plays a strong role in demand for the home countries' exports.

\subsection{Exports and Imports}

Table 6 reports the parameter estimates for the regressions involving exports and imports separately. Columns $I$ and $I I$ provide the results when IIT and VS are not included in the regressions. All else constant, the results suggest that a depreciation in IERER increases export intensity and reduces import intensity. In absolute value, the estimated elasticities are quite similar. As expected, however, they differ in sign. The estimated parameter associated with IERER is negative and significant for the export intensity measure as the dependent variable (column $I$ ). A real depreciation given by a decline in the

\footnotetext{
${ }^{27} \mathrm{We}$ are grateful to an anonymous referee for raising this point.
} 
IERER measure, leads to an increase in export intensity. The estimated parameter associated with IERER is positive and significant for the import intensity measure as the dependent variable (column II). A real depreciation given by a decline in the IERER measure, leads to a decline in import intensity.

The regression results with $I I T$ and $V S$ controls and interactions are reported in columns $I I I$ through $V I$, and corroborate those for the trade balance. When it comes to export intensity, the coefficient associated with $\log (I E R E R)$ is negative and significant. The coefficient associated with the interaction between IIT and $\log (I E R E R)$ is negative, but not significant. The coefficient associated with the interaction between $V S$ and $\log (I E R E R)$ is positive and significant. When it comes to import intensity, the coefficient associated with $\log (I E R E R)$ is positive but not significant (the p-value for the parameter of interest in column $V I$ is $13 \%$ ). The coefficient associated with the interaction between IIT and $\log (I E R E R)$ is positive, but not significant. The coefficient associated with the interaction between $V S$ and $\log (I E R E R)$ is negative and significant.

Similar to the results in Section 4.1, we go beyond the above point estimates and examine two sets of confidence intervals for the elasticity of interest over the entire distribution of IIT and VS. For these estimations we rely on the results reported in columns $I I I$ and $I V$ of Table 6 , in which we control for industry-specific covariates along with time dummies, time trend, and fixed effect. Though the results in columns $I I I$ and $I V$ are quite similar to the results in columns $V$ and $V I$, we again use only the industrylevel covariates in columns $I I I$ and $I V$ which enables us to compute the confidence intervals for varying levels of $I I T$ and $V S$.

Figures 6 and 7 show the effect of variations in IIT and $V S$ on the elasticity of export intensity with respect to IERER. The results are quite similar to what we observe for trade balance elasticity. Export intensity becomes more sensitive to changes in IERER as IIT increases (i.e., when more import substitutes are available). However, it becomes less sensitive as $V S$ increases (i.e., when exports rely more on imported intermediate goods). Figures 8 and 9 show the effect of variations in IIT and VS on the elasticity of import intensity with respect to IERER. We do not find much significance for variations in IIT. As shown in Figure 8, the elasticity of import intensity with respect to IERER is barely significant. It 
is marginally non-zero only at the middle of the IIT distribution. Nevertheless, we find that variations in $V S$ are significant determinants of import intensity elasticity. At low levels of VS, imports are sensitive to changes in IERER. With an increase in VS, however, imports become less sensitive to IERER.

Since in this section we examine export and import intensity, we already include the variations in domestic output, $Q$, as part of the dependent variable. Thus, we do not control for $\log (Q)$ separately. As for other control covariates, the results in Table 6 show that domestic aggregate output, $\log (Y)$, is negatively correlated with both export and import intensities. The US industry-specific output, $\log \left(Q^{U S}\right)$, is positively correlated with export intensity, but it is negatively correlated with import intensity. In the absence of interaction terms (columns $I$ and $I I$ ), foreign aggregate output, $\log \left(Y^{U S}\right)$, is positively correlated with export intensity, but it is not significant. Yet, foreign aggregate output is negatively correlated with import intensity. In the presence of interaction terms (columns $V$ and $V I$ ), the positive correlation between foreign aggregate output and export intensity becomes significant. But the negative correlation between foreign aggregate output and import intensity loses its significance ( $p$-value=15\%).

In short, the results reported in Sections 4.1 and 4.2 suggest that an increase in price competitiveness, as measured by a depreciation in IERER, contributes positively to industry-level trade balances. Controlling for variations in VS and other covariates, we find that an increase in IIT is associated with an increase in the elasticity of industry-level trade balance with respect to IERER. This effect is, in particular, evident through the exports channel (Figures 4, 6, and 8 ). Also, controlling for variations in IIT and other covariates, we find that an increase in $V S$ is associated with a decrease in the elasticity of industry-level trade balance. This correlation is evident through both exports and imports (Figures 5, 7, and 9). In all cases, however, we find that variations in VS are of greater significance when compared to variations in IIT. The emerging pattern helps to clarify the heterogenous responses to a common shock to exchange rates, which makes policy decisions more challenging. 


\subsection{Robustness}

We test for the robustness of the above results. First, we use an alternative measure for foreign industryoutput control. Second, we control for an array of country and industry dummies, and we also interact them with our time variable.

As an alternative to using US output as the foreign industry output control, we control for the industry-specific output in 20 OECD countries. ${ }^{28}$ These countries are large enough; their real GDP in 2015 is at least $1 \%$ of the US real GDP in that year. Also, using the OECD STAN (2020) dataset, we observe their industry-specific output from 2001 to 2014. Except for the Optical and Precision Instruments industry (ISIC Rev. 3 Code: 33), for which we do not consistently observe the output, we aggregate the amount of real industry-specific production for all the industries that are listed in Table 1.

The OECD STAN dataset reports the industry outputs in domestic currencies and in current prices. We transform the OECD data into real figures for each country-industry pair using nominal exchange rates and producer price indexes from the IMF's International Financial Statistics (2020). Then, we aggregate the industry-specific productions to obtain the OECD industry-output. As expected, the share of the US in OECD industry output data is relatively large.${ }^{29}$ Nevertheless, adding the industry outputs from 19 other countries, many of whom are important trade partners for the five Asian countries in our sample, improves the measurement of foreign demand.

We repeat the estimations that correspond to column $V I$ of Table 4 using the OECD industry output. This time, however, we exclude the Optical and Precision Instruments industry for which we do not have a complete set of output information. Column $I$ of Table 7 shows the results using US industry output for this sample while Column II shows results using OECD industry output. The obtained results are comparable to the results reported in column $V I$ of Table 4, suggesting that the effects of changes in

\footnotetext{
${ }^{28}$ The OECD countries that we use are: the US, Germany, France, the UK, Italy, Canada, Spain, Mexico, the Netherlands, Poland, Sweden, Belgium, Austria, Denmark, Finland, Greece, Portugal, Czech Republic, Hungary, and Slovak Republic.

${ }^{29}$ Across all industry-year pairs, about $36 \%$ of OECD industry-specific outputs is made up of the US output.
} 
IERER on trade balances are robust to the choice of foreign demand control. ${ }^{30} \mathrm{We}$ conduct the same exercise for exports and imports in Columns $I I I-V I$ of Table 7, with similar results. Beyond the point estimates, we evaluate the elasticity of trade balance, exports, and imports with respect to IERER at varying levels of IIT and $V S$. Conditional upon the OECD industry-specific output, we find that the exchange rate elasticity of industry-level trade balance increases in IIT and declines in VS and that the obtained confidence intervals follow the patterns observed in Figures 4-9. ${ }^{31}$ We again find that $V S$ variations are more significant than IIT variations, and that exports are more sensitive to changes in IERER.

As an additional robustness check, we add further control covariates, including country and industry dummies, country-time interactions, and industry-time interactions. In Section 3.2, we employ a fixed-effect model for our estimations. Because of that, we are unable to incorporate any time-invariant covariates (e.g., country or industry dummies) into our regression functions unless we re-estimate the parameters of interest using random-effect or least-square-with-dummy-variables (henceforth, LSDV) estimators. Thus, we re-estimate the parameters of interest using random-effect and LSDV estimators, and then add country and industry dummies. We also add the interaction of country and industry dummies with our time variable.

We report the results of this robustness test in Table 8. Column I replicates the key fixed-effect results, reported in column $V I$ of Table 4, using a random-effect estimator. ${ }^{32}$ Like before, we include a time trend and a vector of time dummies. We then add a vector of country dummies and a vector of industry dummies (column $I I$ ). We further add a vector of interactions between country and time dummies (column $I I I$ ) and a vector of interactions between industry and time dummies (column $I V$ ). We also include all of the above dummies and interaction terms in our random effect estimation (column $V$ ).

\footnotetext{
${ }^{30}$ We obtain similar results when we include an OECD industry output control that excludes US output.

${ }^{31}$ Detailed confidence interval estimations are available upon request.

${ }^{32}$ Using the fixed-effect estimator, we allow for correlation between the unobserved country-industry effect $\left(\eta_{c i}\right)$ and other covariates. However, using the random-effect estimator, we need to assume that $\eta_{c i}$ is not correlated with other covariates (Wooldridge, 2002, pp. 251-252). This assumption appears to be harmless as the obtained randomeffect results (column $I$ of Table 8) are in line with fixed-effect results (column VI of Table 4).
} 
Lastly, we estimate the parameters of interest using a LSDV estimator, for which we include a full vector of dummies for country-industry pairs along with the aforementioned vectors of dummies and interactions (column VI). For all of the estimations, we cluster the standard error at country-industry level.

The estimation results are robust to the inclusion of country and industry dummies and their interactions with the time variable. The results suggest that a decline in IERER, corresponding to a depreciation of the industry-specific effective real exchange rate, contributes to trade balance. Its effect is more pronounced when IIT increases, and it is less pronounced when VS increases. For example, consider the results reported in column $I I$ of Table 8 . When all explanatory variables are kept at their means, the absolute value of the exchange rate elasticity of trade balance is equal to $0.81(\mathrm{SE}=0.27)$. It is statistically different from zero, and its magnitude is comparable to the point estimate reported in Table 5 (where we do not control for any country or industry dummies). The absolute value of the elasticity of interest remains statistically significant and increases to $0.98(\mathrm{SE}=0.43)$ when we increase the value of IIT by one standard deviation while all other covariates are kept at their means. In contrast, the absolute value of the elasticity of interest declines to $0.39(\mathrm{SE}=0.24)$ and becomes statistically insignificant when we increase the value of $V S$ by one standard deviation while all other covariates are kept at their means. As before, the $V S$ variations are of greater significance, when compared to IIT variations, indicating that it is important to take into account the global supply chain linkages when considering how real exchange rate movements affect industry trade balances.

\section{Conclusion}

In this study, we explore how the variations in intra-industry trade and vertical specialization affect the elasticity of industry-level trade balances with respect to industry-specific measures of the effective real exchange rate. We also explore the effects of the above variations on the elasticity of industry-level export and import intensities. For this purpose, we employ sample information from 13 manufacturing industries across five Asian countries (China, Japan, Korea, Malaysia, and Indonesia) from 2001 to 2015. Our findings are threefold. First, we find that industry-level trade balances become more elastic as intra-industry trade increases. The impact on the trade balances comes predominantly through 
exports, which are more elastic at higher levels of intra-industry trade, where import substitutes are more readily available. Second, we find that trade balances become less elastic as vertical specialization increases. The channel here is through both exports and imports, which are less elastic at higher levels of vertical specialization, where exports rely more on imported content. Third, we find that the effects from vertical specialization are of greater significance, when compared to intra-industry trade.

Growing uncertainties in the global economy may lead policy makers to actively intervene in foreign exchange markets. All else constant, however, the results of this study suggest that such interventions may be of limited potencies when, for instance, exports rely more heavily on imported content. There are, in fact, leading industries in Asia who have relatively large shares in manufacturing exports and at the same time rely heavily on imported inputs. Electrical Machinery and Apparatus industry is an important example, providing the highest share of exports among industries in China while also indicating high VS and low IIT values. Thus, in response to real depreciation in the yuan, there are likely to be limited changes in the trade balance for this industry, perhaps driving limited changes in the aggregate trade balance as well. Overall, our findings imply that real exchange rate swings, altering relative national prices, have limited effects on trade balances for such industries. This presents a challenge to policy makers who, faced with growing uncertainties, may want to rely on currency intervention for external adjustments in these leading industries.

Further research that examines the impact of tariffs and other trade barriers on these relationships may be warranted. Incorporating industry-specific tariffs is beyond the scope of this paper but we conjecture that such tariffs are likely to impact not only the industry-specific real exchange rates, but also the global patterns for supply chain linkages. Increases in trade barriers may provide incentives for multinationals to engage in horizontal FDI, lowering IIT. Increases in trade barriers may also provide less incentives for multinationals to engage in vertical FDI, lowering VS. 


\section{References}

Ahmed, S., Appendino, M., \& Ruta, M. (2015). Depreciations without exports? Global value chains and the exchange rate elasticity of exports. Policy Research Working Paper 7390, World Bank Group.

Amiti, M., Itskhoki, O., \& Konings, J. (2014). Importers, exporters, and exchange rate disconnect. American Economic Review, 104(7), 1942-78.

Antràs, P. \& Helpman, E. (2004). Global Sourcing. Journal of Political Economy 112: 552-580.

Auer, R. A., \& Schoenle, R. S. (2016). Market structure and exchange rate pass-through. Journal of International Economics, 98, 60-77.

Bahmani-Oskooee, M., \& Hegerty, S. W. (2010). The J-and S-curves: a survey of the recent literature. Journal of Economic Studies, 37(6), 580-596.

Bahmani-Oskooee, M., \& Saha, S. (2017). Asymmetric response of the US-India trade balance to exchange rate changes: Evidence from 68 industries. The World Economy, 40(10), 2226-2254.

Berman, N., Martin, P., \& Mayer, T. (2012). How do different exporters react to exchange rate changes? The Quarterly Journal of Economics, 127(1), 437-492.

Bussiere, M., Gaulier, G., \& Steingress, W. (2020). Global trade flows: Revising the exchange rate elasticities. Open Economies Review 31: 25-78.

Chinn, M.D. (2006). A primer on real effective exchange rates: determinants, overvaluation, trade flows and competitive devaluation. Open Economies Review 17(1): 115-143.

Cieslik, A. (2005). Intra-industry Trade and Relative Factor Endowments. Review of International Economics 13: 904-926.

Clark, D.P., \& Stanley, D.L. (1999). Determinants of intra-industry trade between developing countries and the United States. Journal of Economic Development, 24(2), pp.79-95.

Demiral, M. (2016). Currency Depreciation, Trade Balance and Intra-Industry Trade Interactions in

Turkey's OECD Trade. International Journal of Economics and Finance, 8(4), 8-22.

Falvey, R., Greenaway, D., \& Yu, Z. (2011). Catching up or pulling away: Intra-industry trade, productivity gaps and heterogeneous firms. Open Economies Review, 22(1), pp.17-38.

Feenstra, R. C., Gagnon, J. E., \& Knetter, M. M. (1996). Market share and exchange rate pass-through in world automobile trade. Journal of International Economics, 40(1-2), 187-207.

Garetto, S. (2016). Firms' heterogeneity, incomplete information, and pass-through. Journal of International Economics, 101, 168-179.

Grossman, G. M. \& Rossi-Hansberg, E. (2008). Trading Tasks: A Simple Theory of Offshoring. American Economic Review 98: 1978-1997.

Helpman, E. (1984). A Simple Theory of International Trade with Multinational Corporations. Journal of Political Economy 92: 451-471. 
(1987). Imperfect Competition and International Trade: Evidence from Fourteen Industrial Countries. Journal of the Japanese and International Economies 1: 62-81.

(2011). Understanding Global Trade (Cambridge, MA: Harvard University Press).

Helpman, E. \& Krugman, P. R. (1985). Market Structure and Foreign Trade (Cambridge, MA: MIT Press).

Helpman, E., Melitz, M. J., \& Yeaple, S. R. (2004). Export versus FDI with heterogeneous firms. American Economic Review, 94(1), 300-316.

Hummels, D., Ishii, J., \& Yi, K. M. (2001). The nature and growth of vertical specialization in world trade. Journal of International Economics, 54(1), 75-96.

IMF (International Monetary Fund). (2020). IMF Data. Retrieved from http://www.imf.org/en/Data . (2020). Direction of Trade Statistics. Retrieved from: https://data.imf.org/?sk=9D6028D4-F14A464C-A2F2-59B2CD424B85

Jorgenson, D. W., Ho, M. S., \& Samuels, J. D. (2018). Educational Attainment and the Revival of US Economic Growth. Education, Skills, and Technical Change: Implications for Future US GDP Growth, 77, 23.

Kharroubi, E. (2011). The trade balance and the real exchange rate. BIS Quarterly Review.

Krugman, P. R., Obstfeld, M., \& Melitz, M. J. (2012). International Economics: Theory \& Policy. Addison-Wesley.

Leigh, M. D., Lian, W., Poplawski-Ribeiro, M., Szymanski, R., Tsyrennikov, V., \& Yang, H. (2017). Exchange rates and trade: A disconnect? International Monetary Fund.

Markusen, J. R., \& Venables, A. J. (2000). The theory of endowment, intra-industry and multi-national trade. Journal of International Economics, 52(2), 209-234.

Melitz, M. J., \& Ottaviano, G. I. (2008). Market size, trade, and productivity. The Review of Economic Studies, 75(1), 295-316.

Nguyen, T. N. A., \& Sato, K. (2020). Invoice currency choice, nonlinearities and exchange rate passthrough. Applied Economics, 52(10), 1048-1069.

Oguro, Y. (2011). The sensitivity of export quantities to exchange rates in the context of intra-industry trade. Retrieved from http://hermes-ir.lib.hit-u.ac.jp/rs/bitstream/10086/18924/1/gd10-167.pdf

OECD (Organization for Economic Co-operation and Development). (2010). Measuring Globalisation: OECD Economic Globalisation Indicators 2010. Retrieved from https://doi.org/10.1787/9789264084360-en. . (2020). Structural Analysis (STAN) Database: STAN Database for Structural Analysis (ISIC Rev. 4 SNA08). Retrieved from https://stats.oecd.org. 
. (2019). Structural Analysis (STAN) Database: Input-Output Database - Input-Output Tables (IOTs) ISIC Rev. 3. Retrieved from https://stats.oecd.org.

OPEC (Organization for Petroleum Exporting Countries). 2020. Annual Statistical Bulletin, Table 3.1: World proven crude oil reserves by country. Retrieved from https://asb.opec.org/data/ASB Data.php

Patel, N., Wang, Z., Wei, S-J. (2019). Global value chains and effective exchange rates at the countrysector level. Journal of Money, Credit, and Banking 51(S1): 7-42.

Research Institute of Economy, Trade, and Industry. (2017). Industry-specific Nominal and Real Effective Exchange Rates of 18 Countries Worldwide. Retrieved from http://www.rieti.go.jp/users/eeri/en/.

Sato, K., Shimizu, J., Shrestha, N., \& Zhang, S. (2015). Industry-specific real effective exchange rates in Asia. RIETI Discussion Papers.

Song, E.Y. and Sohn, C.H. (2012). Intra-industry Trade and Industry Distribution of Productivity: A Cournot-Ricardo Approach. The World Economy, 35(4), pp.461-482

Tabrizy, S. (2020). Industrial Research and Development and Real Exchange Rate Depreciation in a Small Open Economy. The World Economy, Forthcoming.

UNIDO (United Nations Industrial Development Organization). 2017. Industrial Statistics Database: INDSTAT4 - 2016 Edition at the 3- and 4-digit Level of ISIC Revision 3 and ISIC Revision 4. Retrieved from https://stat.unido.org

United Nations Statistics Division. (2002). International Standard Industrial Classification of All Economic Activities, Rev. 3. Retrieved from https://unstats.un.org/unsd/statcom/doc02/isic.pdf

Veeramani, C. (2009). Trade barriers, multinational involvement and intra-industry trade: panel data evidence from India. Applied Economics, 41(20), 2541-2553.

Wooldridge, J. M. (2002). Econometric analysis of cross section and panel data. MIT press.

World Bank. 2017. World Integrated Trade Solution. Retrieved from http://wits.worldbank.org

World Bank Data. (2019a). Exports of Goods and Services (current US\$), World Bank National Account Data and OECD National Account Data Files. Retrieved from https://data.worldbank.org/indicator/NE.EXP.GNFS.CD . (2019b). GDP (constant 2010 US\$) World Bank National Account Data and OECD National Account Data Files. Retrieved from https://data.worldbank.org/indicator/NY.GDP.MKTP.KD

Yoshida, Y. (2013). Market share and exchange rate pass-through competition among exporters of the same nationality. RIETI Discussion Papers. 
Tables and Figures

Table 1: Industries Included in Our Dataset

\begin{tabular}{ll}
\hline ISIC R3 Code & Industry Name (Abbreviated Name) \\
\hline $15-16$ & Food, Beverage, and Tobacco (Food) \\
$17-19$ & Textile, Textile Products, Leather, and Footwear (Textile) \\
20 & Wood Products, excluding Furniture (Wood) \\
$21-22$ & Paper, Paper Products, Printing, and Publishing (Paper) \\
23 & Coke, Refined Petroleum Products, and Nuclear Fuel (Petroleum) \\
24 & Chemicals and Chemical Products (Chemical) \\
25 & Rubber and Plastics Products (Rubber) \\
26 & Non-metallic Mineral Products (Non-metal) \\
$27-28$ & Basic Metals and Fabricated Metal Products (Metal) \\
29 & Machinery and Equipment, N.E.C. (General Mach.) \\
$30-32$ & Electrical Machinery and Apparatus N.E.C. (Electrical Mach.) \\
33 & Optical and Precision Instruments (Optical Inst.) \\
$34-35$ & Transportation Equipment (Transp. Eq.) \\
\hline
\end{tabular}

Table 2: Summary Statistics for Key Variables by Industry

\begin{tabular}{|c|c|c|c|c|c|c|c|c|c|c|}
\hline \multirow[t]{2}{*}{ Industry } & \multicolumn{2}{|c|}{$\log (T B)$} & \multicolumn{2}{|c|}{ Export Intensity } & \multicolumn{2}{|c|}{ Import Intensity } & \multicolumn{2}{|c|}{$\begin{array}{l}\text { Intra-Industry } \\
\text { Trade Index }\end{array}$} & \multicolumn{2}{|c|}{$\begin{array}{c}\text { Vertical } \\
\text { Specialization } \\
\text { Index } \\
\end{array}$} \\
\hline & Median & IQR & Median & IQR & Median & IQR & Median & IQR & Median & IQR \\
\hline Food & 0.19 & 2.09 & 0.06 & 0.27 & 0.13 & 0.06 & 0.51 & 0.20 & 0.11 & 0.22 \\
\hline Textile & 0.43 & 2.16 & 0.40 & 0.37 & 0.22 & 0.44 & 0.48 & 0.59 & 0.22 & 0.18 \\
\hline Wood & 0.67 & 5.47 & 0.10 & 0.66 & 0.13 & 0.25 & 0.15 & 0.19 & 0.17 & 0.14 \\
\hline Paper & -0.26 & 0.52 & 0.13 & 0.17 & 0.14 & 0.09 & 0.77 & 0.2 & 0.22 & 0.12 \\
\hline Petro & .42 & 1.32 & 0.24 & 0.31 & 0.20 & 0.12 & 0.7 & 0.3 & 0.36 & 0.33 \\
\hline Che & .02 & 0.65 & & 0.16 & & 0.29 & 0.84 & 0.1 & 0.26 & 0.21 \\
\hline Rub & 79 & 0.25 & 0 & 0.07 & 0 & 0.8 & 0. & & 0.24 & 0.17 \\
\hline Non-n & 0.43 & 1.29 & 0.12 & 0.1 & 0. & 0.10 & 0. & 0.31 & 0.19 & 0.18 \\
\hline Metal & 0 & 0.93 & 0.21 & 0.28 & 0.21 & 0.53 & 0.79 & 0.21 & 0.29 & 0.23 \\
\hline Gener & 0.01 & 1.02 & 0.43 & 0.50 & 0.38 & 1.80 & 0.75 & 0.41 & 0.34 & 0.23 \\
\hline Electrical Mach. & 0.47 & 0.33 & 0.43 & 0.71 & 0.27 & 0.58 & 0.75 & 0.14 & 0.36 & 0.23 \\
\hline Optical Inst. & -0.02 & 0.79 & 1.76 & 1.43 & 2.04 & 1.73 & 0.80 & 0.23 & 0.36 & 0.23 \\
\hline Transp. Eq. & 0.14 & 2.86 & 0.30 & 0.23 & 0.09 & 0.38 & 0.47 & 0.40 & 0.26 & 0.15 \\
\hline
\end{tabular}

Note: The inter-quartile range (IQR) measures the spread around the median. It is defined as the difference between the value of the third quartile $\left(75^{\text {th }}\right.$ percentile) and the value of the first quartile ( $25^{\text {th }}$ percentile).

Table 3: Summary Statistics for Key Variables

\begin{tabular}{lccccc}
\hline Variable & No. of Obs. & Mean & S.D. & Min. & Max. \\
\hline $\log (T B)$ & 975 & 0.046 & 1.232 & -4.91 & 3.803 \\
$\log (x)$ & 733 & 3.075 & 1.315 & -1.58 & 7.429 \\
$\log (m)$ & 733 & 3.066 & 1.245 & 0.223 & 8.542 \\
$\log (I E R E R)$ & 975 & 4.65 & 0.231 & 4.077 & 5.735 \\
$\operatorname{IIT}$ & 975 & 0.641 & 0.257 & 0.015 & 0.999 \\
$\operatorname{VS}$ & 715 & 0.287 & 0.153 & 0.052 & 0.84 \\
$\log (Q)$ & 733 & 24.452 & 1.86 & 16.828 & 28.378 \\
$\log \left(Q^{U S}\right)$ & 885 & 26.387 & 0.806 & 24.879 & 27.577 \\
$\log (Y)$ & 975 & 27.925 & 1.236 & 25.819 & 29.818 \\
$\log \left(Y^{U S}\right)$ & 975 & 30.321 & 0.073 & 30.183 & 30.445 \\
\hline
\end{tabular}

Notes: $T B$ is trade balance, $x$ is exports divided by output, $m$ is imports divided by output, IERER is effective real exchange rate, IIT is intra-industry trade measure, $V S$ is vertical specialization measure, and $Q$ is output - all of these variables are for countryindustry pairs. $Y$ is country-level real GDP. $Q^{U S}$ is industry-level real output in the US, and $Y^{U S}$ is real GDP for the US. 
Table 4: Trade Balance Regressions

\begin{tabular}{|c|c|c|c|c|c|c|c|}
\hline & $\begin{array}{c}I \\
\log (T B)\end{array}$ & $\begin{array}{c}I I \\
\log (T B) \\
\end{array}$ & $\begin{array}{c}I I I \\
\log (T B)\end{array}$ & $\begin{array}{c}I V \\
\log (T B)\end{array}$ & $\begin{array}{c}V \\
\log (T B) \\
\end{array}$ & $\begin{array}{c}V I \\
\log (T B)\end{array}$ & $\begin{array}{c}V I I \\
\log (T B)\end{array}$ \\
\hline $\log ($ IERER $)$ & $\begin{array}{c}-0.908 * * * \\
(0.288)\end{array}$ & $\begin{array}{c}-0.834 * * * \\
(0.291)\end{array}$ & $\begin{array}{c}-1.034 * * \\
(0.442)\end{array}$ & $\begin{array}{c}-1.592 * * * \\
(0.355)\end{array}$ & $\begin{array}{c}-1.309^{* * *} \\
(0.421)\end{array}$ & $\begin{array}{c}-1.172 * * \\
(0.462)\end{array}$ & $\begin{array}{c}-1.187 * * * \\
(0.427)\end{array}$ \\
\hline IIT & & & $\begin{array}{l}-1.756 \\
(3.912)\end{array}$ & & $\begin{array}{c}2.220 \\
(4.089)\end{array}$ & $\begin{array}{c}2.354 \\
(4.027)\end{array}$ & $\begin{array}{c}2.585 \\
(3.956)\end{array}$ \\
\hline$I I T \times \log (I E R E R)$ & & & $\begin{array}{c}0.262 \\
(0.840)\end{array}$ & & $\begin{array}{l}-0.559 \\
(0.868)\end{array}$ & $\begin{array}{l}-0.609 \\
(0.865)\end{array}$ & $\begin{array}{l}-0.653 \\
(0.847)\end{array}$ \\
\hline$V S$ & & & & $\begin{array}{c}-10.790 * * * \\
(3.506)\end{array}$ & $\begin{array}{c}-12.263 * * * \\
(4.295)\end{array}$ & $\begin{array}{c}-12.595 * * * \\
(3.773)\end{array}$ & $\begin{array}{c}-13.033^{* * *} \\
(3.840)\end{array}$ \\
\hline$V S \times \log (I E R E R)$ & & & & $\begin{array}{c}2.205^{* * *} * \\
(0.685)\end{array}$ & $\begin{array}{c}2.533 * * * \\
(0.877)\end{array}$ & $\begin{array}{c}2.631 * * * \\
(0.779)\end{array}$ & $\begin{array}{c}2.694 * * * \\
(0.786)\end{array}$ \\
\hline $\log (Q)$ & $\begin{array}{c}0.335^{* *} \\
(0.155)\end{array}$ & $\begin{array}{l}0.201^{*} \\
(0.115)\end{array}$ & $\begin{array}{c}0.283^{*} \\
(0.160)\end{array}$ & $\begin{array}{l}0.312^{* *} \\
(0.149)\end{array}$ & $\begin{array}{l}0.292^{*} \\
(0.160)\end{array}$ & $\begin{array}{c}0.104 \\
(0.069)\end{array}$ & $\begin{array}{c}0.175 \\
(0.109)\end{array}$ \\
\hline $\log (Y)$ & $\begin{array}{l}-0.629 \\
(0.421)\end{array}$ & $\begin{array}{c}-0.401 \\
(0.323)\end{array}$ & $\begin{array}{c}-0.537 \\
(0.472)\end{array}$ & $\begin{array}{l}-0.528 \\
(0.397)\end{array}$ & $\begin{array}{l}-0.480 \\
(0.429)\end{array}$ & & $\begin{array}{c}-0.284 \\
(0.344)\end{array}$ \\
\hline $\log \left(Q^{U S}\right)$ & & $\begin{array}{c}0.422 * * \\
(0.170)\end{array}$ & & & & $\begin{array}{l}0.401^{*} \\
(0.211)\end{array}$ & $\begin{array}{l}0.368^{*} \\
(0.194)\end{array}$ \\
\hline $\log \left(Y^{U S}\right)$ & & $\begin{array}{c}12.781^{* *} \\
(4.888)\end{array}$ & & & & & $\begin{array}{l}65.222 * * \\
(31.037)\end{array}$ \\
\hline No. of Obs. & 733 & 707 & 733 & 620 & 620 & 615 & 615 \\
\hline R-squared & 0.225 & 0.283 & 0.250 & 0.227 & 0.247 & 0.287 & 0.292 \\
\hline Fixed effect & Yes & Yes & Yes & Yes & Yes & Yes & Yes \\
\hline Time dummies & Yes & Yes & Yes & Yes & Yes & Yes & Yes \\
\hline Time trend & Yes & Yes & Yes & Yes & Yes & Yes & Yes \\
\hline Constant term & Yes & Yes & Yes & Yes & Yes & Yes & Yes \\
\hline
\end{tabular}

Notes: Refer to the notes in Table 3 for variable definitions. Robust standard errors clustered at the country-industry level are reported in parentheses. $* * * p$-value $<0.01, * *$ p-value $<0.05$, and $* p$-value $<0.1$.

Table 5: Trade Balance Elasticity

\begin{tabular}{cccccc}
\hline Lower limit & Point estimate & Upper limit & $I I T$ & $V S$ & Other variables \\
\hline-1.32 & -0.79 & -0.25 & Mean $_{I I T}$ & Mean $_{V S}$ & Mean \\
-1.79 & -0.95 & -0.10 & Mean $_{I I T}+\mathrm{SD}_{I I T}$ & Mean $_{V S}$ & Mean \\
-0.85 & -0.38 & +0.10 & Mean $_{I I T}$ & Mean $_{V S}+\mathrm{SD}_{V S}$ & Mean \\
\hline
\end{tabular}

Note: These $95 \%$ confidence intervals are computed using the estimation results reported in Table 4, column VI. 
Table 6: Exports and Imports Regressions

\begin{tabular}{|c|c|c|c|c|c|c|}
\hline & $\begin{array}{c}I \\
\log (x)\end{array}$ & $\begin{array}{c}I I \\
\log (m)\end{array}$ & $\begin{array}{c}I I I \\
\log (x)\end{array}$ & $\begin{array}{c}I V \\
\log (m)\end{array}$ & $\begin{array}{c}V \\
\log (x)\end{array}$ & $\begin{array}{c}V I \\
\log (m) \\
\end{array}$ \\
\hline$\overline{L o g}(I E R E R)$ & $\begin{array}{c}-0.578 * * * \\
(0.179)\end{array}$ & $\begin{array}{l}0.571^{*} \\
(0.300)\end{array}$ & $\begin{array}{c}-0.802 * * \\
(0.368)\end{array}$ & $\begin{array}{l}1.037^{*} \\
(0.589)\end{array}$ & $\begin{array}{c}-0.803 * * \\
(0.376)\end{array}$ & $\begin{array}{c}0.963 \\
(0.632)\end{array}$ \\
\hline IIT & & & $\begin{array}{c}1.979 \\
(2.723)\end{array}$ & $\begin{array}{l}-1.298 \\
(3.984)\end{array}$ & $\begin{array}{c}2.026 \\
(2.557)\end{array}$ & $\begin{array}{l}-1.118 \\
(4.075)\end{array}$ \\
\hline$I I T \times \log (I E R E R)$ & & & $\begin{array}{l}-0.443 \\
(0.563)\end{array}$ & $\begin{array}{c}0.417 \\
(0.868)\end{array}$ & $\begin{array}{l}-0.438 \\
(0.527)\end{array}$ & $\begin{array}{c}0.388 \\
(0.888)\end{array}$ \\
\hline$V S$ & & & $\begin{array}{c}-7.272 * * \\
(3.480)\end{array}$ & $\begin{array}{c}12.410 * * * \\
(3.862)\end{array}$ & $\begin{array}{c}-7.711 * * \\
(3.762)\end{array}$ & $\begin{array}{c}11.208 * * * \\
(3.774)\end{array}$ \\
\hline$V S \times \log (I E R E R)$ & & & $\begin{array}{c}1.667 * * \\
(0.710)\end{array}$ & $\begin{array}{c}-2.392 * * * \\
(0.765)\end{array}$ & $\begin{array}{c}1.670 * * \\
(0.773)\end{array}$ & $\begin{array}{c}-2.228 * * * \\
(0.757)\end{array}$ \\
\hline $\log (Y)$ & $\begin{array}{c}-0.620 * * * \\
(0.210)\end{array}$ & $\begin{array}{c}-0.455^{* *} \\
(0.227)\end{array}$ & & & $\begin{array}{c}-0.506 * * \\
(0.237)\end{array}$ & $\begin{array}{c}-0.493^{* *} \\
(0.210)\end{array}$ \\
\hline $\log \left(Q^{U S}\right)$ & $\begin{array}{c}0.465^{* * *} \\
(0.142)\end{array}$ & $\begin{array}{c}-0.339 * * * \\
(0.116)\end{array}$ & $\begin{array}{c}0.438 * * \\
(0.170)\end{array}$ & $\begin{array}{c}-0.292 * * \\
(0.140)\end{array}$ & $\begin{array}{c}0.446^{* * *} \\
(0.157)\end{array}$ & $\begin{array}{c}-0.255^{*} \\
(0.144)\end{array}$ \\
\hline $\log \left(Y^{U S}\right)$ & $\begin{array}{c}4.381 \\
(3.627)\end{array}$ & $\begin{array}{c}-12.040^{* * *} \\
(4.209)\end{array}$ & & & $\begin{array}{l}52.774 * * \\
(23.056)\end{array}$ & $\begin{array}{c}-39.934 \\
(27.302)\end{array}$ \\
\hline $\log (x)$ & & $\begin{array}{c}0.531 * * * \\
(0.116)\end{array}$ & & $\begin{array}{c}0.599 * * * \\
(0.103)\end{array}$ & & $\begin{array}{c}0.533 * * * \\
(0.121)\end{array}$ \\
\hline $\log (m)$ & $\begin{array}{c}0.393 * * * \\
(0.101) \\
\end{array}$ & & $\begin{array}{c}0.518 * * * \\
(0.090)\end{array}$ & & $\begin{array}{c}0.457 * * * \\
(0.108) \\
\end{array}$ & \\
\hline No. of Obs. & 707 & 707 & 615 & 615 & 615 & 615 \\
\hline R-squared & 0.465 & 0.375 & 0.462 & 0.445 & 0.487 & 0.465 \\
\hline Fixed effect & Yes & Yes & Yes & Yes & Yes & Yes \\
\hline Time dummies & Yes & Yes & Yes & Yes & Yes & Yes \\
\hline Time trend & Yes & Yes & Yes & Yes & Yes & Yes \\
\hline Constant term & Yes & Yes & Yes & Yes & Yes & Yes \\
\hline
\end{tabular}


Table 7: Trade Balance, Exports, and Imports Regressions Controlling for the US or OECD Industry Output

\begin{tabular}{|c|c|c|c|c|c|c|}
\hline & $\begin{array}{c}I \\
\log (T B)\end{array}$ & $\begin{array}{c}I I \\
\log (T B)\end{array}$ & $\begin{array}{c}I I I \\
\log (x)\end{array}$ & $\begin{array}{c}I V \\
\log (x)\end{array}$ & $\begin{array}{c}V \\
\log (m)\end{array}$ & $\begin{array}{c}V I \\
\log (m)\end{array}$ \\
\hline$\overline{\log (I E R E R)}$ & $\begin{array}{c}-1.051 * * \\
(0.485)\end{array}$ & $\begin{array}{c}-1.074 * * \\
(0.502)\end{array}$ & $\begin{array}{l}-0.710^{*} \\
(0.386)\end{array}$ & $\begin{array}{l}-0.735^{*} \\
(0.389)\end{array}$ & $\begin{array}{c}0.885 \\
(0.637)\end{array}$ & $\begin{array}{c}0.900 \\
(0.656)\end{array}$ \\
\hline$I I T$ & $\begin{array}{c}2.597 \\
(4.103)\end{array}$ & $\begin{array}{c}2.582 \\
(4.145)\end{array}$ & $\begin{array}{c}1.533 \\
(2.636)\end{array}$ & $\begin{array}{c}1.522 \\
(2.673)\end{array}$ & $\begin{array}{l}-1.898 \\
(4.036)\end{array}$ & $\begin{array}{l}-1.881 \\
(4.080)\end{array}$ \\
\hline$I I T \times \log (I E R E R)$ & $\begin{array}{l}-0.695 \\
(0.877)\end{array}$ & $\begin{array}{l}-0.690 \\
(0.884)\end{array}$ & $\begin{array}{l}-0.358 \\
(0.543)\end{array}$ & $\begin{array}{l}-0.353 \\
(0.550)\end{array}$ & $\begin{array}{c}0.580 \\
(0.871)\end{array}$ & $\begin{array}{c}0.575 \\
(0.879)\end{array}$ \\
\hline$V S$ & $\begin{array}{c}-12.651 * * * \\
(3.741)\end{array}$ & $\begin{array}{c}-12.971 * * * \\
(3.804)\end{array}$ & $\begin{array}{l}-6.374^{*} \\
(3.639)\end{array}$ & $\begin{array}{l}-6.757^{*} \\
(3.607)\end{array}$ & $\begin{array}{c}12.731 * * * \\
(3.882)\end{array}$ & $\begin{array}{c}12.939 * * * \\
(3.982)\end{array}$ \\
\hline$V S \times \log (I E R E R)$ & $\begin{array}{c}2.684 * * * \\
(0.772)\end{array}$ & $\begin{array}{c}2.747 * * * \\
(0.791)\end{array}$ & $\begin{array}{l}1.508 * * \\
(0.747)\end{array}$ & $\begin{array}{l}1.583 * * \\
(0.746)\end{array}$ & $\begin{array}{c}-2.479 * * * \\
(0.762)\end{array}$ & $\begin{array}{c}-2.518 * * * \\
(0.783)\end{array}$ \\
\hline $\log (Q)$ & $\begin{array}{l}0.135^{*} \\
(0.072)\end{array}$ & $\begin{array}{l}0.136^{*} \\
(0.075)\end{array}$ & & & & \\
\hline $\log \left(Q^{U S}\right)$ & $\begin{array}{l}0.404^{*} \\
(0.219)\end{array}$ & & $\begin{array}{c}0.456 * * \\
(0.171)\end{array}$ & & $\begin{array}{c}-0.279 * * \\
(0.134)\end{array}$ & \\
\hline $\log \left(Q^{O E C D}\right)$ & & $\begin{array}{l}0.547^{*} \\
(0.321)\end{array}$ & & $\begin{array}{c}0.632 * * \\
(0.244)\end{array}$ & & $\begin{array}{l}-0.372 * \\
(0.192)\end{array}$ \\
\hline $\log (x)$ & & & & & $\begin{array}{c}0.542 * * * \\
(0.115)\end{array}$ & $\begin{array}{c}0.539 * * * \\
(0.114)\end{array}$ \\
\hline $\log (m)$ & & & $\begin{array}{c}0.449 * * * \\
(0.081)\end{array}$ & $\begin{array}{c}0.446 * * * \\
(0.081)\end{array}$ & & \\
\hline No. of Obs. & 590 & 590 & 590 & 590 & 590 & 590 \\
\hline R-squared & 0.307 & 0.303 & 0.434 & 0.432 & 0.418 & 0.415 \\
\hline Fixed effect & Yes & Yes & Yes & Yes & Yes & Yes \\
\hline Time dummies & Yes & Yes & Yes & Yes & Yes & Yes \\
\hline Time trend & Yes & Yes & Yes & Yes & Yes & Yes \\
\hline Constant term & Yes & Yes & Yes & Yes & Yes & Yes \\
\hline $\begin{array}{l}\text { Notes: Refer to } t \\
\text { Precision Instrun } \\
\text { industry-specific }\end{array}$ & $\begin{array}{l}\text { tes in Ta } \\
\text { industry. } \\
\text { it for } 20\end{array}$ & $\begin{array}{l}\text { and } 4 . \mathrm{D} \\
\text { is US rea } \\
\mathrm{D} \text { memb }\end{array}$ & $\begin{array}{l}\text { data av } \\
\text { istry-sp }\end{array}$ & $\begin{array}{l}\text { y, we e } \\
\text { atput, a }\end{array}$ & $\begin{array}{l}\text { e the Opti } \\
E C D \text { is the }\end{array}$ & $\begin{array}{l}\text { and } \\
\text { gregate real }\end{array}$ \\
\hline
\end{tabular}


Table 8: Trade Balance Regressions Using More Dummies and Interactions

\begin{tabular}{|c|c|c|c|c|c|c|}
\hline & $\begin{array}{c}I \\
\log (T B)\end{array}$ & $\begin{array}{c}I I \\
\log (T B)\end{array}$ & $\begin{array}{c}I I I \\
\log (T B)\end{array}$ & $\begin{array}{c}I V \\
\log (T B)\end{array}$ & $\begin{array}{c}V \\
\log (T B)\end{array}$ & $\begin{array}{c}V I \\
\log (T B)\end{array}$ \\
\hline & \multicolumn{5}{|c|}{ Random-effect estimations } & $L S D V$ \\
\hline \multirow[t]{2}{*}{$\log (I E R E R)$} & $-1.137 * *$ & $-1.168 * * *$ & $-1.075^{* * *}$ & $-1.200 * * *$ & $-1.035^{* *}$ & $-1.187 * * *$ \\
\hline & $(0.466)$ & $(0.438)$ & $(0.371)$ & $(0.388)$ & $(0.412)$ & $(0.416)$ \\
\hline \multirow[t]{2}{*}{ IIT } & 2.364 & 2.669 & 1.061 & 4.664 & 2.644 & 1.678 \\
\hline & $(4.057)$ & $(3.965)$ & $(2.964)$ & $(3.026)$ & (2.393) & $(2.572)$ \\
\hline \multirow[t]{2}{*}{$I I T \times \log (I E R E R)$} & -0.611 & -0.669 & -0.312 & $-1.115^{*}$ & -0.669 & -0.487 \\
\hline & $(0.871)$ & $(0.852)$ & $(0.641)$ & $(0.645)$ & $(0.511)$ & $(0.547)$ \\
\hline \multirow[t]{2}{*}{$V S$} & $-12.332 * * *$ & $-12.853 * * *$ & $-6.250 *$ & $-17.841 * * *$ & $-9.745^{*}$ & -8.936 \\
\hline & (3.718) & $(3.756)$ & $(3.635)$ & $(4.045)$ & (5.184) & (5.538) \\
\hline \multirow[t]{2}{*}{$V S \times \log (I E R E R)$} & $2.570 * * *$ & $2.675 * * *$ & $1.463^{*}$ & $3.664 * * *$ & $2.169^{* *}$ & $2.099 *$ \\
\hline & $(0.769)$ & $(0.779)$ & $(0.750)$ & $(0.911)$ & $(1.092)$ & $(1.176)$ \\
\hline \multirow{2}{*}{$\log (Q)$} & 0.089 & $0.137^{*}$ & $0.198 * *$ & $0.153^{* *}$ & $0.276^{* * *}$ & 0.118 \\
\hline & $(0.059)$ & $(0.072)$ & $(0.100)$ & $(0.073)$ & $(0.101)$ & $(0.094)$ \\
\hline \multirow[t]{2}{*}{$\log \left(Q^{U S}\right)$} & $0.366^{*}$ & $0.385^{*}$ & $0.342^{* *}$ & -0.806 & -0.307 & -0.314 \\
\hline & $(0.198)$ & $(0.216)$ & $(0.162)$ & $(1.045)$ & $(1.304)$ & $(1.384)$ \\
\hline No. of Obs. & 615 & 615 & 615 & 615 & 615 & 615 \\
\hline R-squared & 0.287 & 0.286 & 0.5048 & 0.419 & 0.621 & 0.987 \\
\hline Random effect & Yes & Yes & Yes & Yes & Yes & No \\
\hline Country-industry dummies & No & No & No & No & No & Yes \\
\hline Time dummies & Yes & Yes & Yes & Yes & Yes & Yes \\
\hline Time trend & Yes & Yes & Yes & Yes & Yes & Yes \\
\hline Country dummies & No & Yes & Yes & Yes & Yes & Yes \\
\hline Industry dummies & No & Yes & Yes & Yes & Yes & Yes \\
\hline Country-time dummies & No & No & Yes & No & Yes & Yes \\
\hline Industry-time dummies & No & No & No & Yes & Yes & Yes \\
\hline Constant term & Yes & Yes & Yes & Yes & Yes & Yes \\
\hline
\end{tabular}


Figure 1. Industry-specific Median of Time-varying Measure for IIT (by Country)

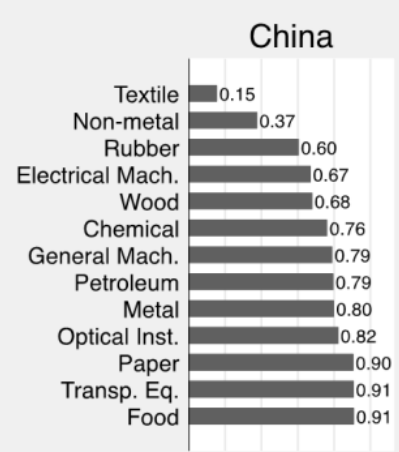

Korea

Wood 0.09

Transp. Eq. $\quad 0.27$

Food $\quad 0.49$

Non-metal $\quad 0.56$

Optical Inst. $\quad 0.68$

Rubber $\quad 0.71$

Electrical Mach. $\quad 0.73$

Petroleum $\quad 0.80$

Textile $\quad 0.90$

Chemical $\quad 0.90$

Paper $\quad 0.91$

Metal 0.93

General Mach.
Indonesia

Wood $\quad 0.15$

General Mach. 0.35

Petroleum $\quad 0.36$

Textile $\quad 0.48$

Food $\quad 0.51$

Transp. Eq. 0.52

Paper $\quad 0.55$

Optical Inst. $\quad 0.64$

Chemical 0.72

Electrical Mach 0.72

$\begin{array}{rr}\text { Non-metal } & 0.77 \\ \text { Rubber } & 0.79\end{array}$

Metal $\square .89$

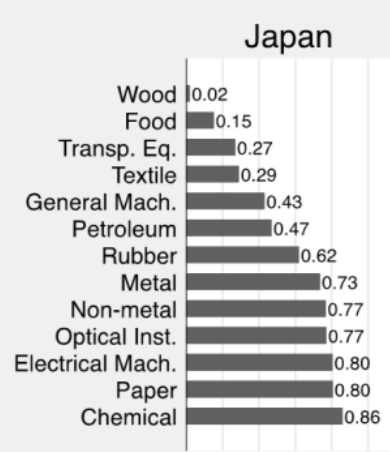

Malaysia

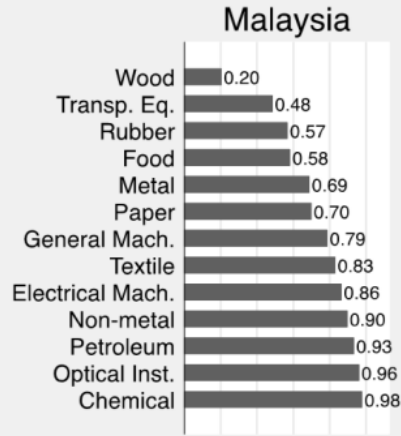

Figure 2. Industry-specific Median of Time-varying Measure for VS (by Country)

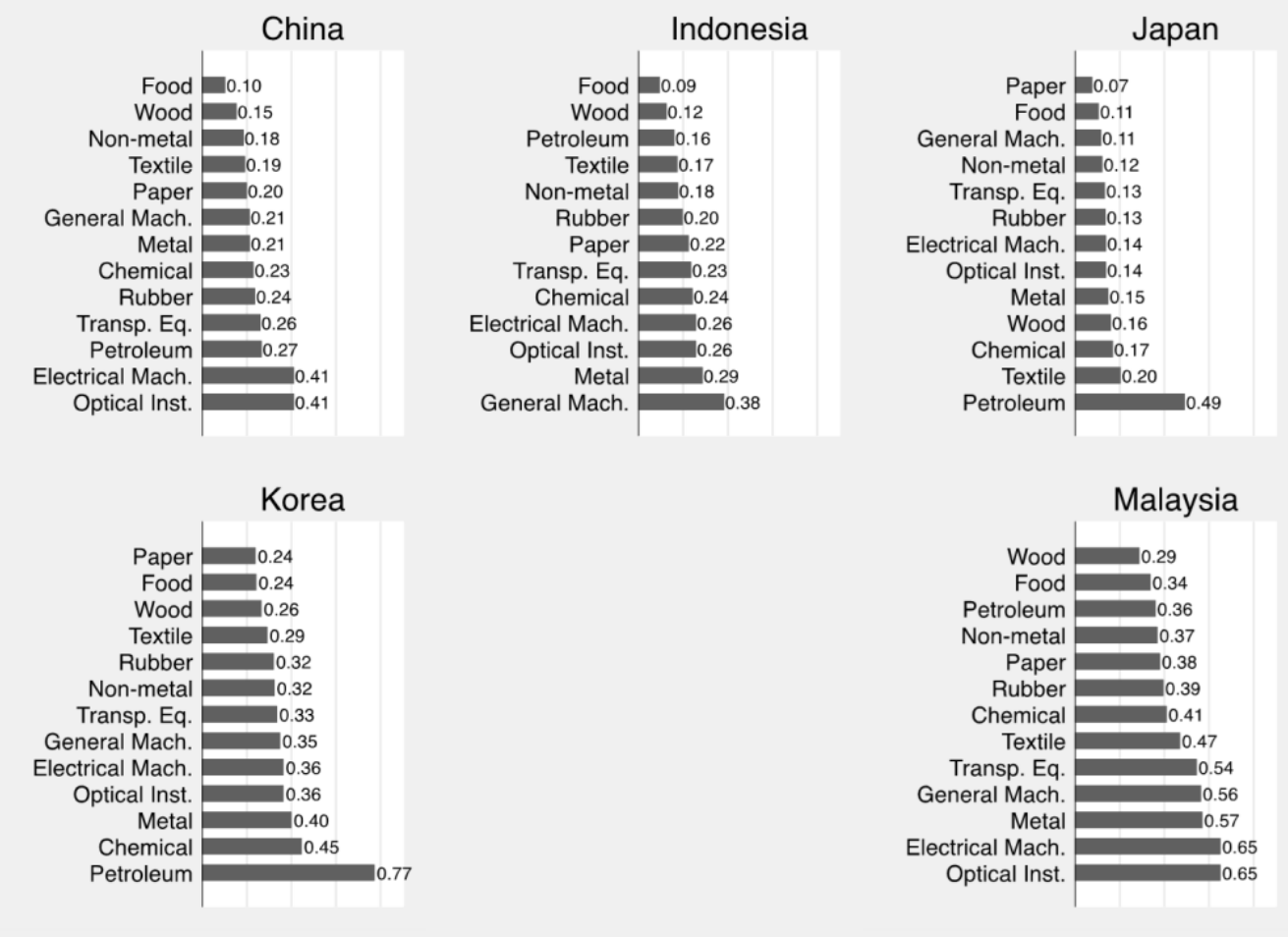


Figure 3. Industry-specific effective real exchange rates, IERER

China

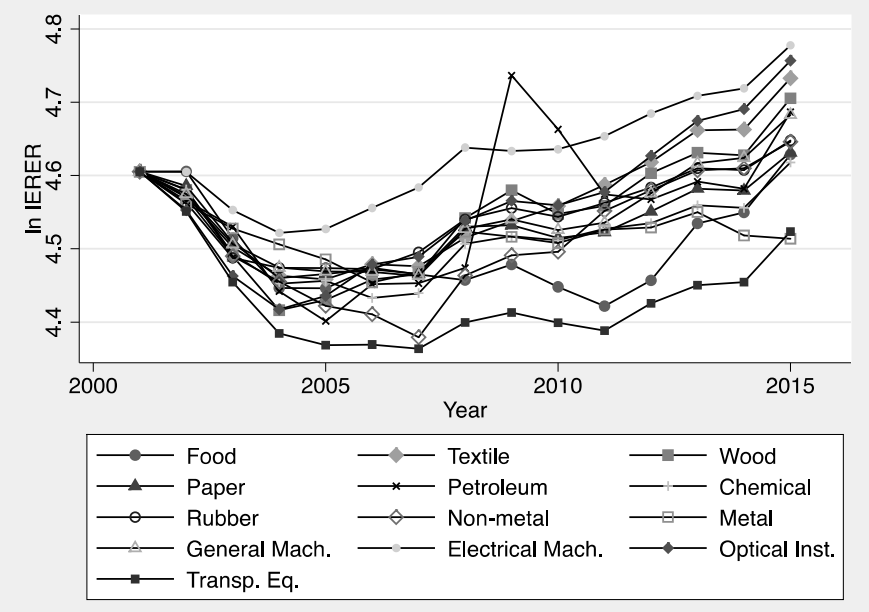

Indonesia
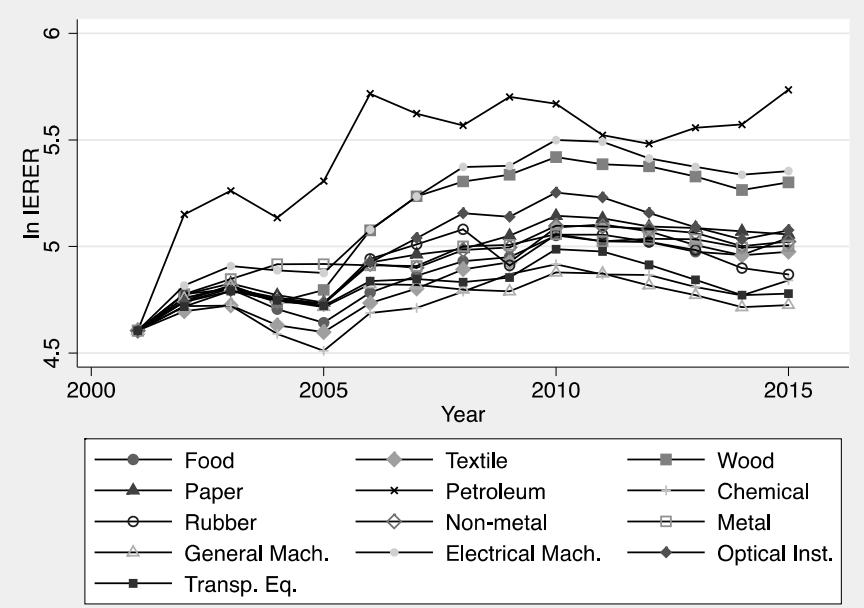

Japan

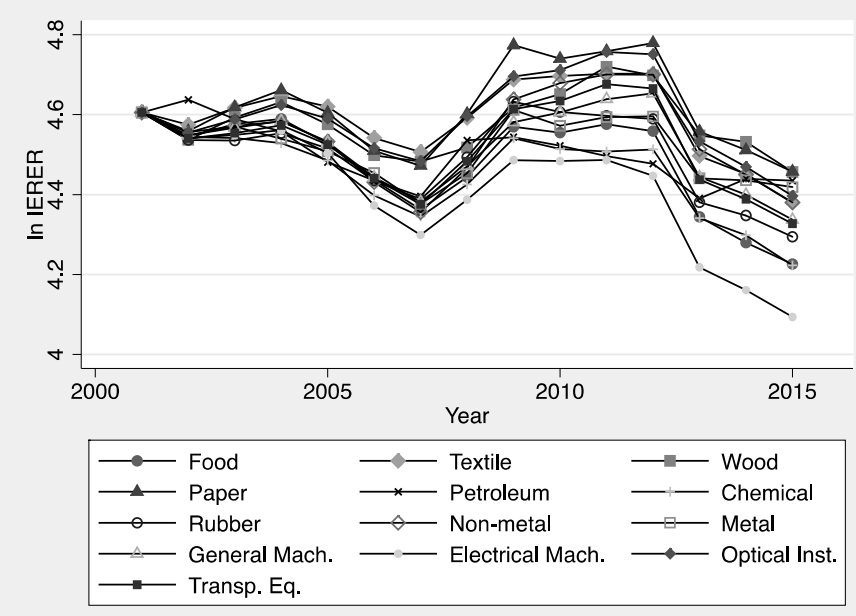


Figure 3 (cont'd).

Korea

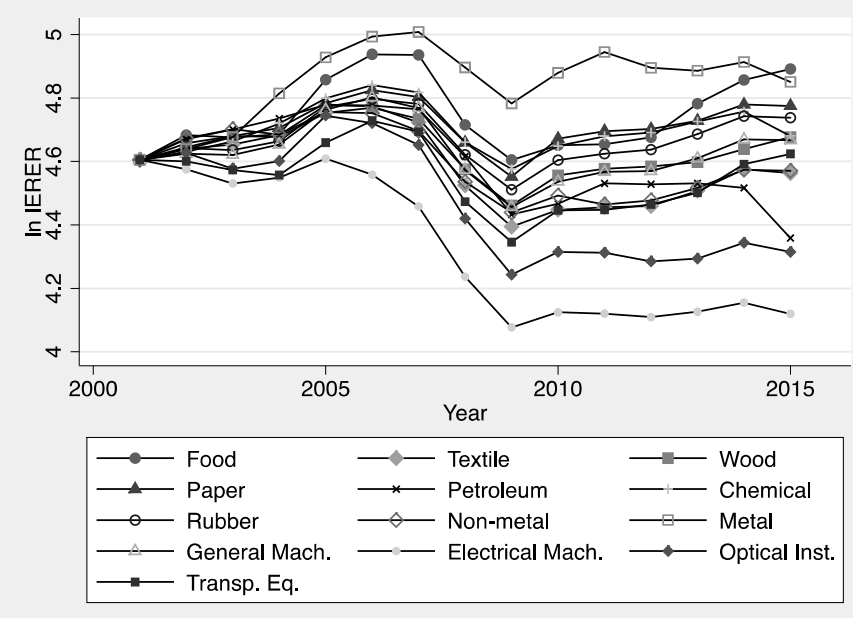

Malaysia

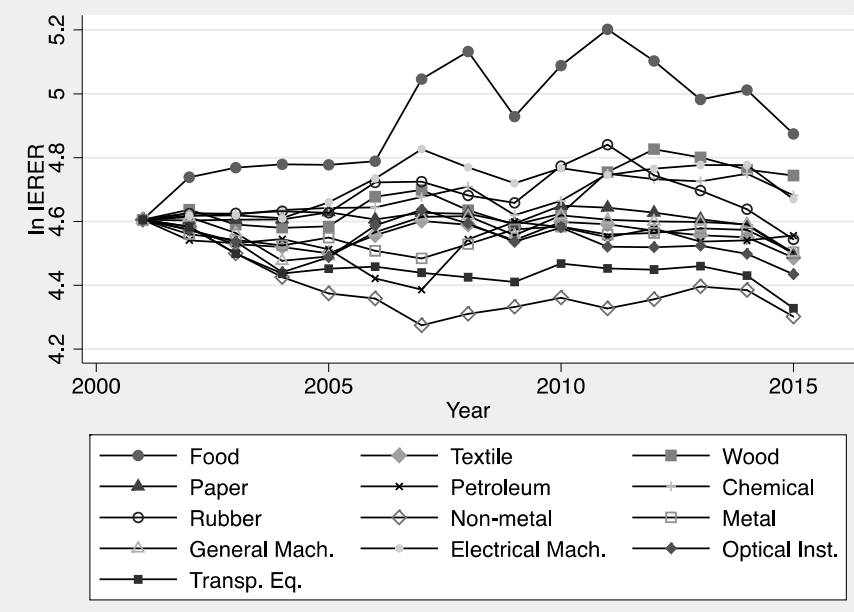


Figure 4. Trade Balance Elasticity at Varying Levels of IIT

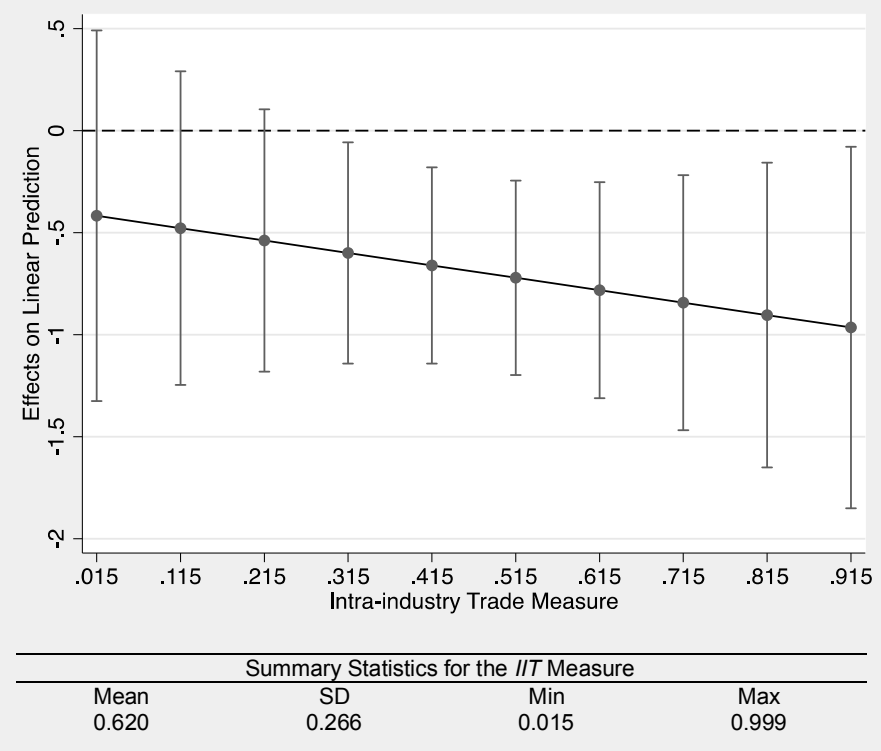

Figure 5. Trade Balance Elasticity at Varying Levels of VS

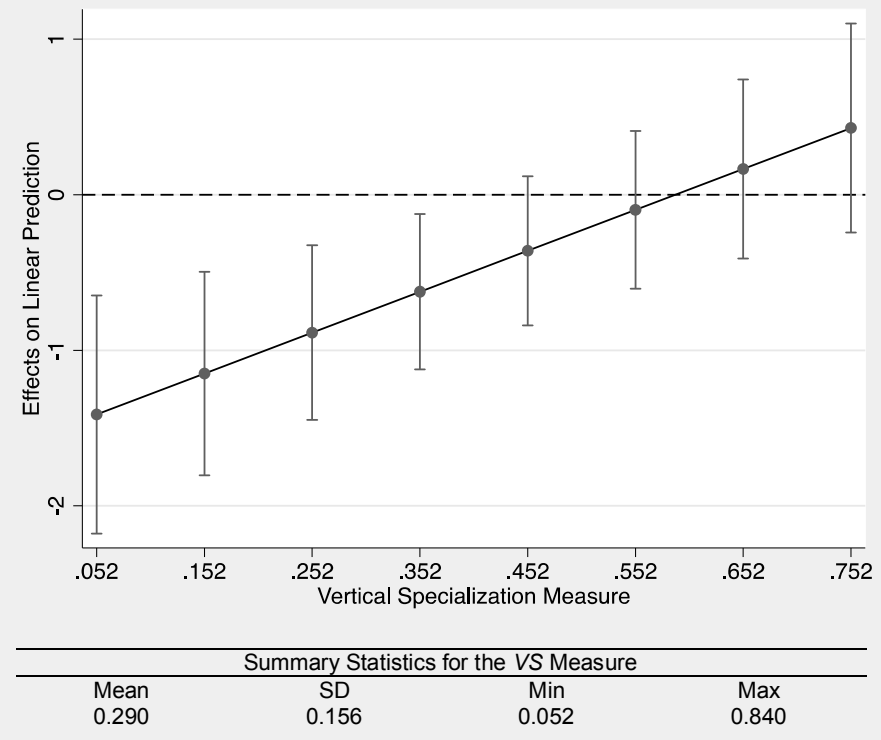


Figure 6. Export Intensity Elasticity at Varying Levels of IIT

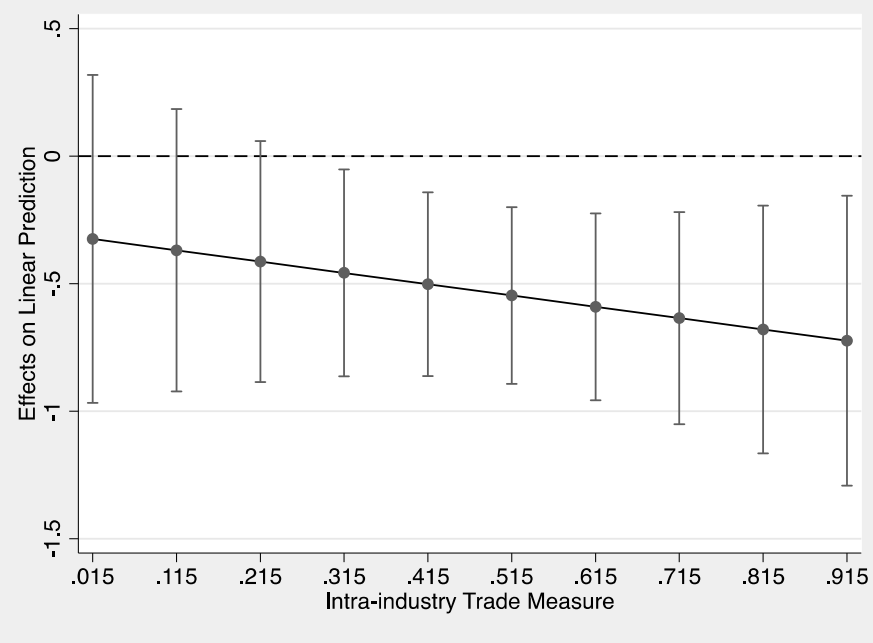

Note: The summary statistics for the IIT measure are given in Figure 4.

Figure 7. Export Intensity Elasticity at Varying Levels of $V S$

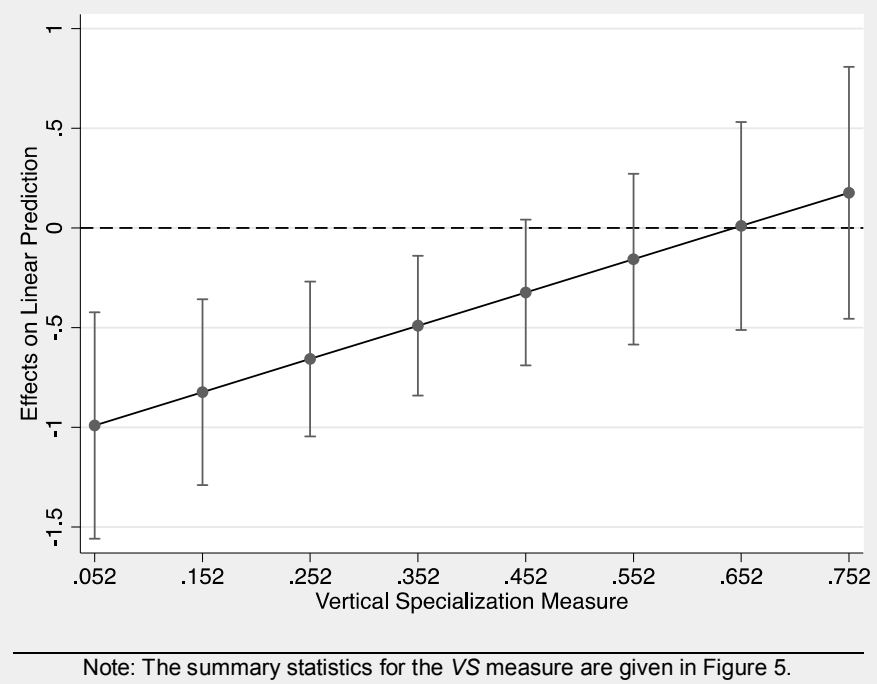


Figure 8. Import Intensity Elasticity at Varying Levels of IIT

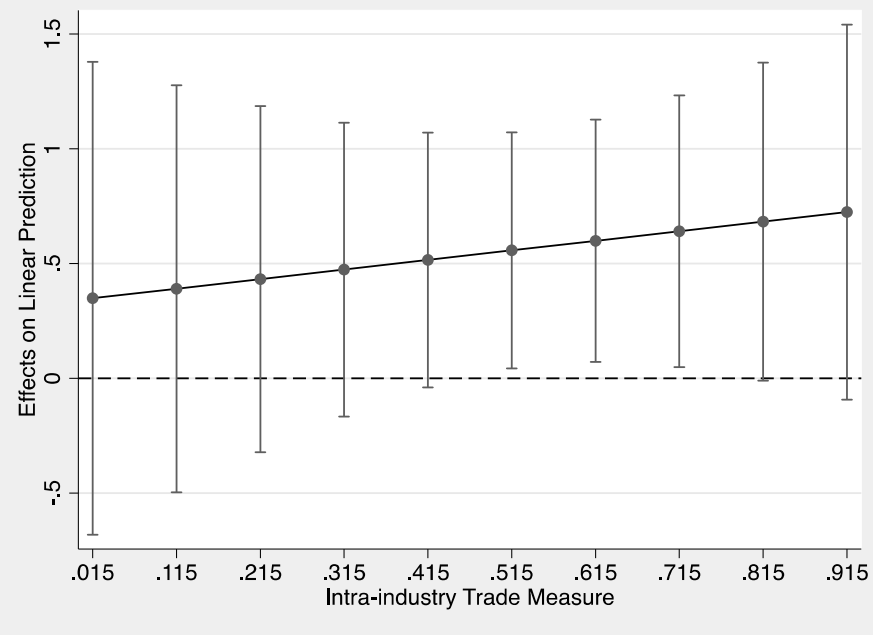

Note: The summary statistics for the IIT measure are given in Figure 4.

Figure 9. Import Intensity Elasticity at Varying Levels of $V S$

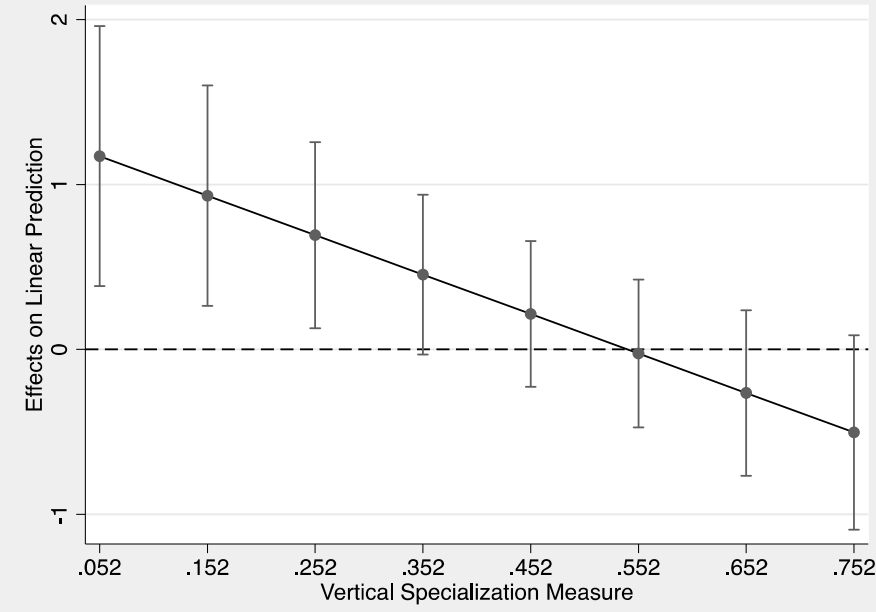

Note: The summary statistics for the VS measure are given in Figure 5. 


\section{Appendix}

Table A1: Pairwise Correlation Coefficients for IIT and VS

\begin{tabular}{lcc}
\hline & Median $I I T$ and Median $V S$ & $I I T$ and $V S$ \\
\hline China & 0.1138 & 0.1706 \\
Indonesia & 0.2478 & 0.2546 \\
Japan & -0.1274 & -0.1192 \\
Korea & 0.2826 & 0.3128 \\
Malaysia & 0.3823 & 0.3916 \\
\hline All Countries & 0.2971 & 0.3107 \\
\hline
\end{tabular}

Figure A1. Industry-specific Trade Balances

\section{China}

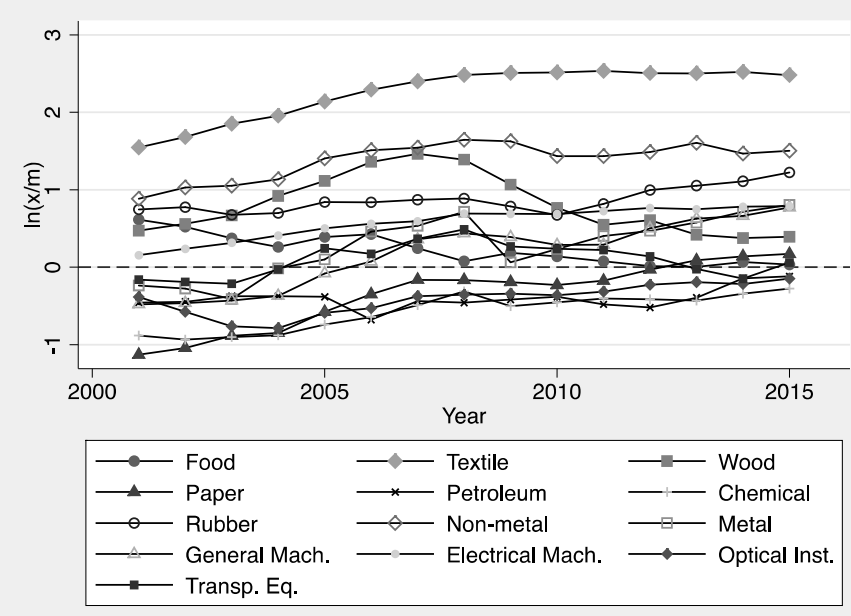

Indonesia

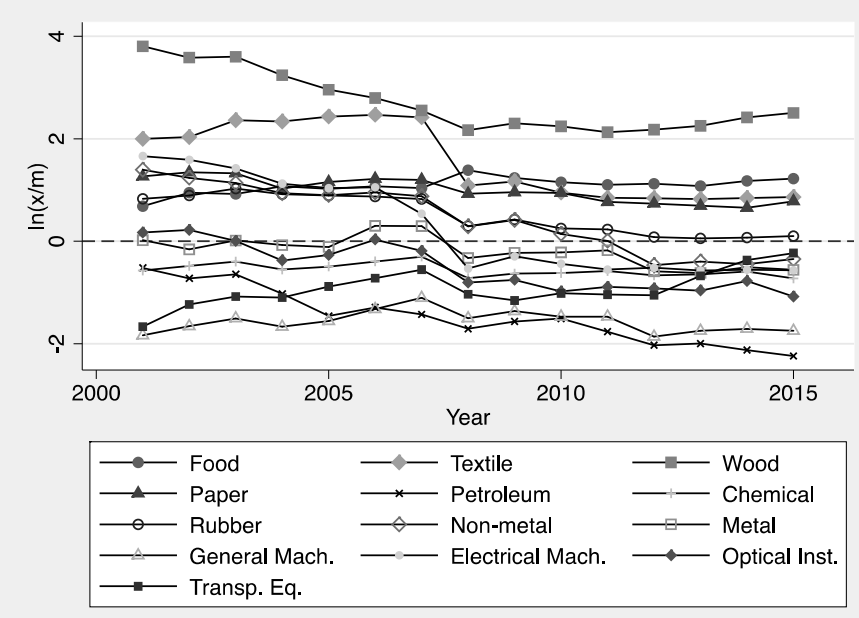


Figure A1 (cont'd).

Japan

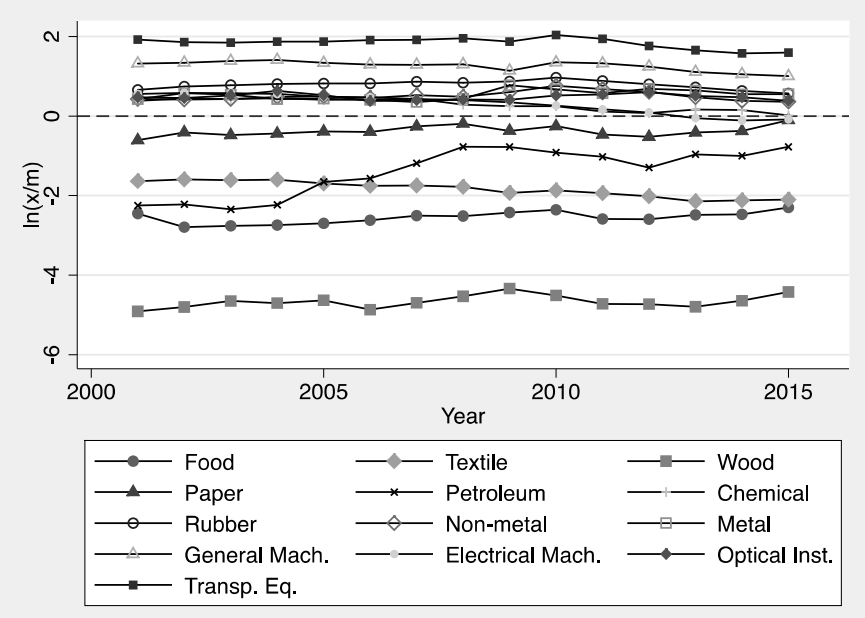

\section{Korea}

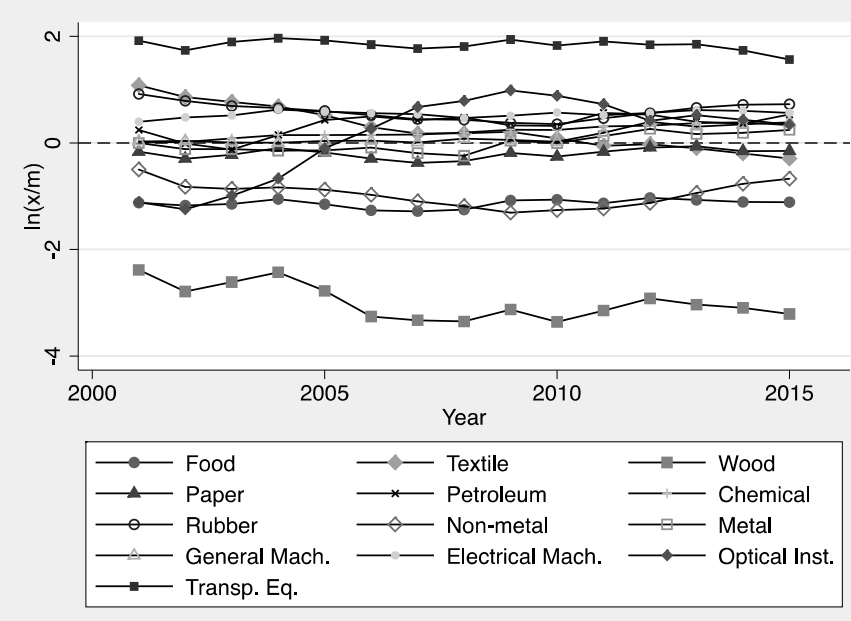

Malaysia

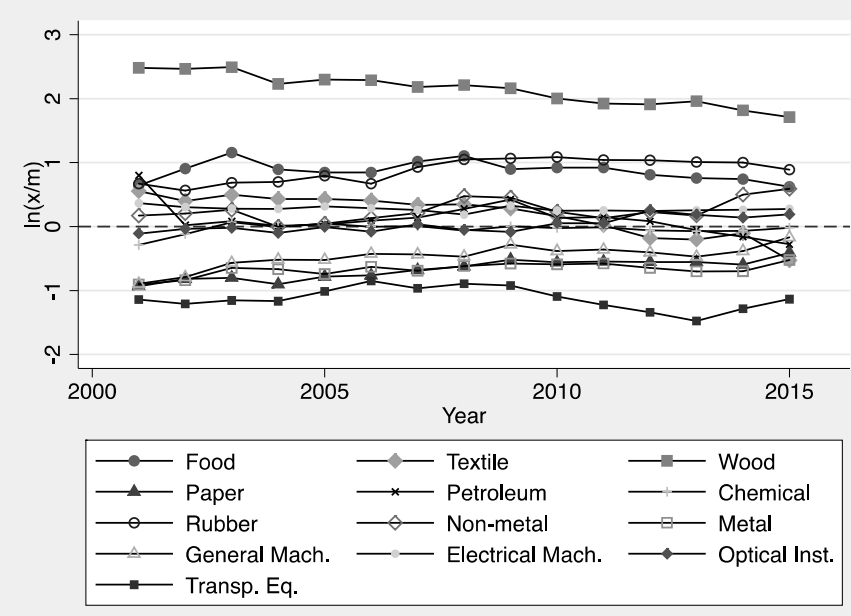


Figure A2. Histogram of Variations in Trade Balances

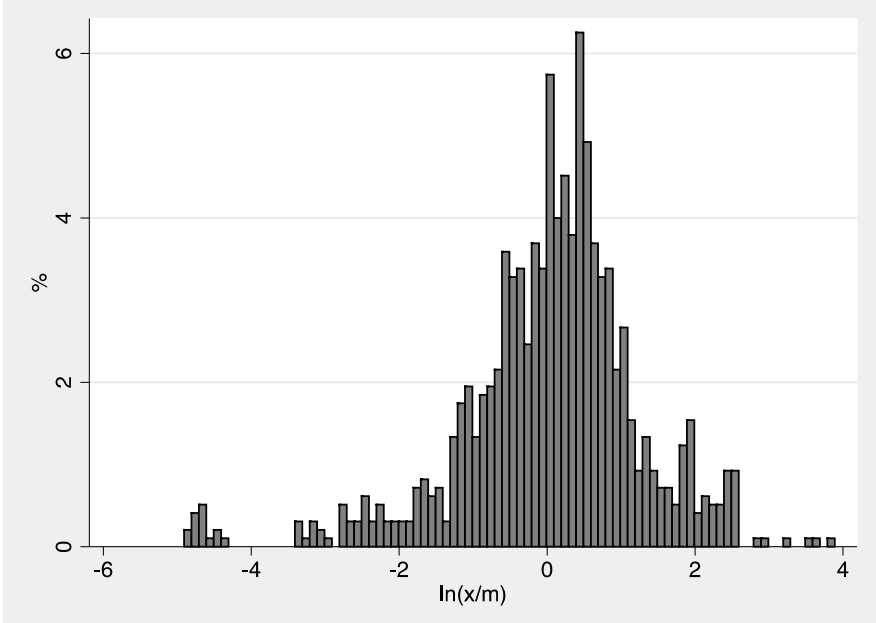

Figure A3. Histogram of variations in IIT among the observations that are included in Table 4, column VI

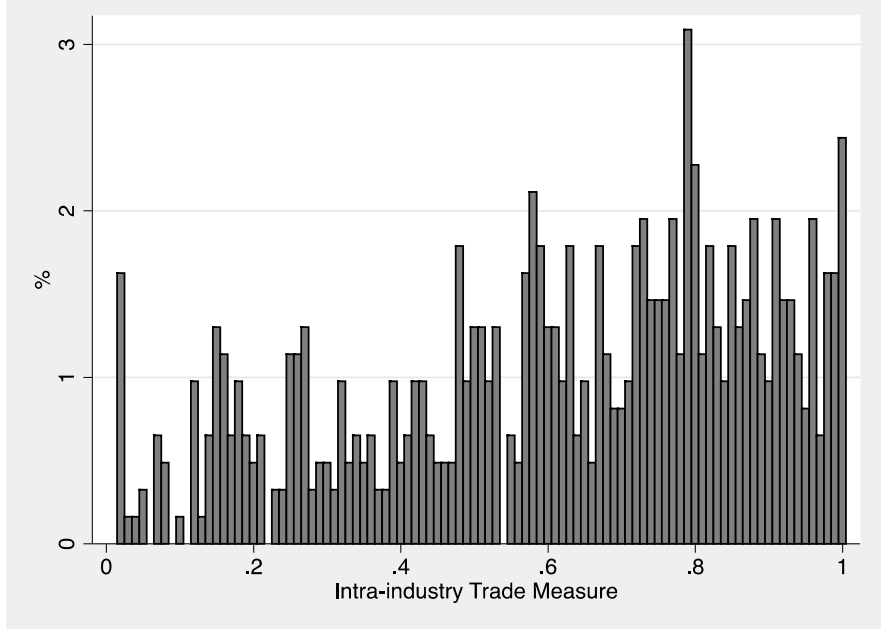

Figure A4. Histogram of variations in $V S$ among the observations that are included in Table 4, column $V I$

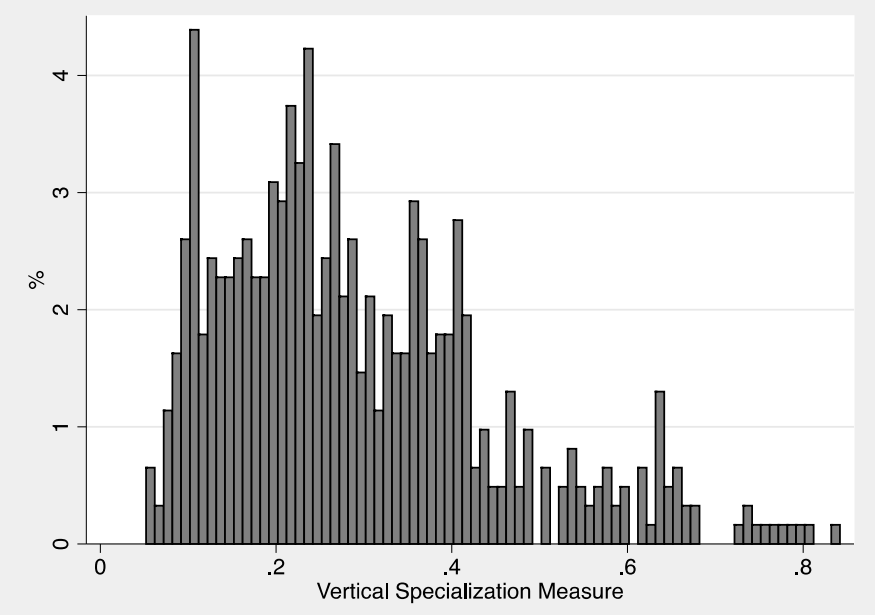


Figure A5. Industry-specific Median IIT and VS

\section{China}
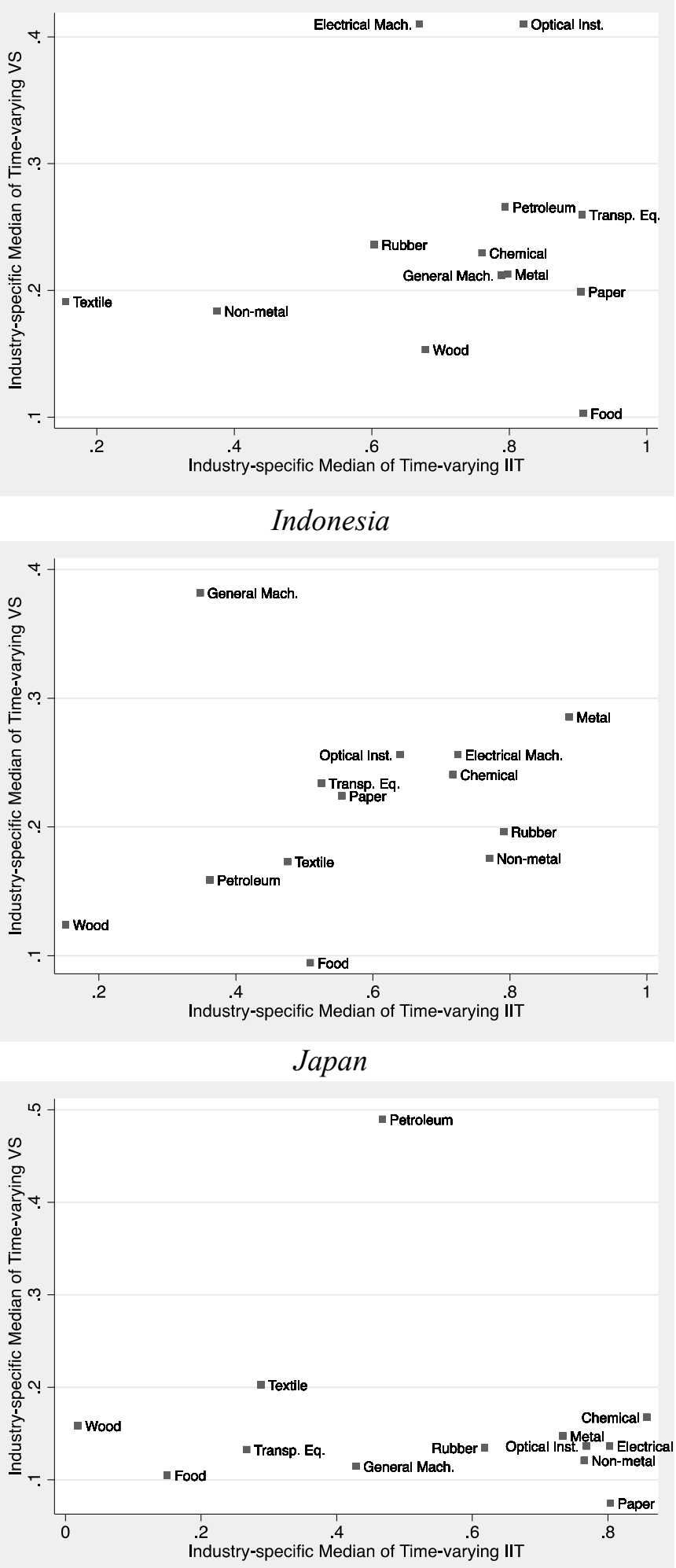
Figure A5 (cont'd).

Korea
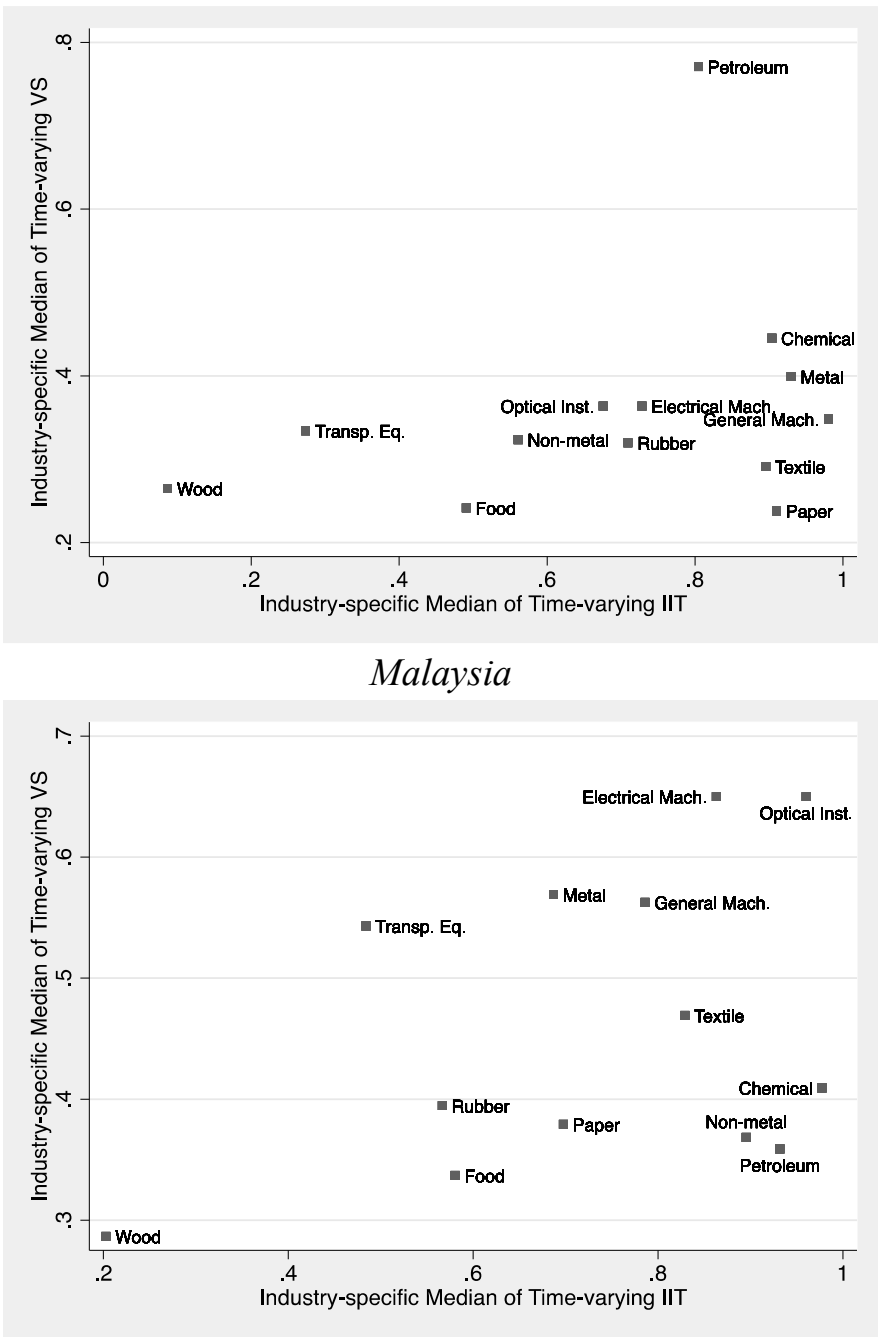